\title{
POLITICAL PROPHECY IN ELIZABETHAN ENGLAND
}

\author{
Talia Pollock
}

A thesis submitted to the Victoria University of Wellington in fulfilment of the requirements for the degree of Master of Arts

Victoria University of Wellington 2013 



\section{CONTENTS}

Acknowledgements $\quad$ ii

Abbreviations $\quad$ iii

Abstract iv

Introduction 1

Chapter One (1558-1572) 8

Chapter Two (1572-1588) 28

Chapter Three (1588-1603) 49

Conclusion $\quad 64$

Bibliography $\quad 66$ 


\section{ACKNOWLEDGEMENTS}

I would like to thank both of my supervisors: Glyn Parry for introducing me to the fascinating history of religion and magic in early modern England, encouraging me to pursue this topic as an MA, and providing invaluable feedback and advice; and Steve Behrendt for stepping in when Glyn left for England and guiding me with the writing process. I would also like to thank my fellow postgraduates in the History Department at VUW for their solidarity and support, and especially Florence Baggett, Matthew Vink, and Daniel Cruden for proof-reading. Finally, thanks to my friends and family for their support over the past year. 


\section{ABBREVIATIONS}

BL

$\mathrm{CP}$

CSP Scotland

CSP Spanish

DL

DU

PC

SP

TNA
British Library

Cecil Papers, Hatfield House

Calendar of State Papers relating to Scotland and Mary Queen of Scots, 13 vols. (Edinburgh, 1898-1969).

Calendar of Letters and State Papers relating to England and Spain, 19 vols. (London, 1862-1947).

Records of the Duchy of Lancaster

Dudley Papers

Privy Council

State Papers

The National Archives (UK) 


\begin{abstract}
This thesis examines political prophecy in England during the reign of Elizabeth I (15581603). The belief that foreknowledge of events could be attained through means such as the practice of astrology, revelation from God, or the interpretation of supposedly prophetic texts was widespread in English society during the early modern period. This thesis discusses how those both within and outside of the government used prophecy in their engagement with the political issues which faced England during Elizabeth's reign, especially in relation to religion and the succession. Because prophecy offered a source of authority for political change it was often employed in opposition to established authorities, prompting legislation criminalising seditious prophecies and printed works condemning them. By examining a wide range of primary sources, including assize records, Privy Council reports, depositions, diplomatic and administrative correspondence, and printed tracts and sermons, this thesis reveals how prophecy pervaded the political culture of Elizabethan England.
\end{abstract}




\section{INTRODUCTION}

In 1559 the Scottish diplomat James Melville rested at Newcastle en route to France. There he met a varlet of the Queen's chamber, who told him that Henry VIII had consulted diviners to learn the fate of his children. The diviners had told King Henry that his son Edward would not have children and that his daughters, Mary and Elizabeth, would rule in succession. Further, Mary would marry a Spaniard, which would cause "great stryf and alteration" in England, and Elizabeth would marry a Scotsman or Frenchman. In an attempt to prevent these marriages Henry had poisoned his two daughters but, "finding them selues alterit be vehement vomiting," they "tok some remedy" and survived. The poison, however, rendered Mary unable to have children, "for sche was sindre tymes supponit to be with chyld to the Kyng Phillip of Spain, yet brocht fourth na thing bot dead lomps of flesch, and monsters." Melville believed the varlet's tale and, when he was asked by the Duke Casimir of the Palatinate in 1561 to take a marriage proposal to Elizabeth on his behalf, he refused "vpon the conceat that I had that sche, knowing hir self vnable for succession... wald not render hir self subiect till any man."

The varlet's story, whether true or not, exemplifies how prophecy threaded through the politics of Elizabeth's reign. This thesis will demonstrate that prophecy provided a common mode of expression in Elizabethan England by which people engaged with the major political issues of the time-in the varlet's case, the crucial matter of Elizabeth's marriage and ability to produce an heir. Despite this, the historiography of Elizabeth's reign has largely neglected the role prophecy played in the political machinations of the period. This largely reflects the prejudices of those who compiled the Calendars of State Papers, the basis for so much of our historical research on the Tudor period. Because late Victorian intellectuals took an extremely rational attitude towards the past, cataloguers often omitted references to prophecy in the state manuscripts.

In order to more fully understand the politics of Elizabeth's reign we must take the prophetic beliefs of sixteenth-century men and women seriously. There has been some effort to do this: in a 2005 article K. J. Kesselring pointed out how the use of prophecies in sixteenth-century protests challenges the usual characterization of riots and rebellions

\footnotetext{
${ }^{1}$ James Melville, Memoirs of his own life (Edinburgh: Bannatyne Club, 1827) pp.82-4, 90.
} 
as conservative and deferential, suggesting "a popular political culture with room for greater transformative aims than we usually allow." 2 To expand on her work requires a more thorough exploration of the primary source material on political prophecy in Elizabethan England than has yet been done. This thesis has used online databases of digitised primary sources such as State Papers Online, Cecil Papers and EEBO in order to uncover as much evidence as possible relating to political prophecy in Elizabethan England.

\section{Political Prophecy in English History}

When Elizabeth inherited the throne in November 1558 political prophecy already had a long history in England, originating in the twelfth century with Geoffrey of Monmouth's Prophetiae Merlini (the Prophecies of Merlin). Studies of the history of prophecy have thus far primarily focussed on the medieval era, Henry VIII's reign, or the Civil War period. Elizabeth's reign has been underexplored by comparison, and much of the work which does discuss this period is historically limited because of its literary focus.

The first modern scholarly treatment of political prophecy in English history was Rupert Taylor's 1911 book The Political Prophecy in England. Taylor defined political prophecy as "any expression of thought, written or spoken, in which an attempt is made to foretell coming events of a political nature," yet focussed his study exclusively on its literary manifestations. ${ }^{3}$ He distinguished between direct and symbolical prophecies and identified two primary methods of disguise used in the latter: Sybillic, which originated in Europe and used initials to refer to historical actors; and Galfridian, which originated with Geoffrey of Monmouth and used animal symbolism. ${ }^{4}$

Whereas Taylor focused on political prophecy as a literary genre, in 2000 Lesley Coote argued that it should instead be treated as a discourse. She emphasised that "writers, copyists and audience all participated in the creation of each political prophecy, and might go on re-creating it as circumstances changed." She argued that political prophecy began as "a means of vocalizing what it meant to be "English," and by the time of Edward II had "also become a means of expressing fundamental beliefs about the relationship of king, people and nation." The "dynastic struggles of the fifteenth century"

\footnotetext{
${ }^{2}$ K. J. Kesselring, 'Deference and Dissent in Tudor England: Reflections on Sixteenth-Century Protest', History Compass, Vol. 163, no. 3, 2005, p.8.

${ }^{3}$ Rupert Taylor, The Political Prophecy in England (New York: Columbia University Press, 1911) p.2.

${ }^{4}$ Ibid., pp.3, 8-9.

${ }^{5}$ Lesley A. Coote, Prophecy and Public Affairs in Later Medieval England (Woodbridge: Boydell \& Brewer, 2000) pp.13, 15.
} 
then led to its "use as a partisan tool." Her study ended in 1485 with the foundation of the Tudor dynasty after the Battle of Bosworth, though she acknowledged that prophecy continued to be used thereafter. ${ }^{6}$

Among the Tudors, Henry VIII's reign has received the most attention from historians studying political prophecy. A short article by Madeleine Hope Dodds published in Modern Language Review in 1916 summarised some of the instances where prophecies influenced Henrician political ideas, particularly during the Pilgrimage of Grace. $^{7}$ G. R. Elton's 1972 study of the enforcement of the Reformation under Thomas Cromwell included a chapter on "Rumour, Magic and Prophecy" which emphasised the danger posed to the regime by "the less rational attacks on the general state of mind... the dissemination of false hopes and fears." ${ }^{\text { A }} 1983$ article by Jonathan van Patten discussed the legal response of Henry's government to magic and prophecy, and in 1986 Alistair Fox sought to explain why political prophecies were so popular during Henry's reign. ${ }^{9}$ In 1991 Sharon Jansen's book Political Protest and Prophecy under Henry VIII analysed the role of prophecies as a form of political protest, asserting that by the 1530s prophecy had been transformed from "a tool to make or control popular opinion" into "a source of power and authority for popular protest." 10

Keith Thomas's 1971 book Religion and the Decline of Magic included a more general study of prophecy in England during the sixteenth and seventeenth centuries, with sections on religious prophecy and astrology as well as ancient prophecy (a term he applies to both Galfridian and Sybillic prophecies in that "they drew their prestige from their antiquity.") He argued that prophecy functioned not only as a propaganda device but also as a "validating charter." As people in early modern England believed the existing political order to be divinely ordained rather than socially constructed, it was necessary to disguise revolutionary changes by "concealing" them "under the sanction of past approval."11

\footnotetext{
${ }^{6}$ Ibid., p.237.

${ }^{7}$ Madeleine Hope Dodds, 'Political Prophecies in the Reign of Henry VIII', Modern Language Review, Vol. 11, no. 3, July 1916, pp.276-284.

${ }^{8}$ G. R. Elton, Policy and Police: The Enforcement of the Reformation in the Age of Thomas Cromwell (Cambridge: Cambridge University Press, 1972) p.46.

9 Jonathan K. van Patten, 'Magic, Prophecy, and the Law of Treason in Reformation England', The American Journal of Legal History, Vol. 27, no. 1, January 1983, pp.1-32; Alistair Fox, 'Prophecies and Politics in the Reign of Henry VIII', in Alistair Fox and John Guy, Reassessing the Henrician Age: Humanism, Politics and Reform, 1500-1550 (Oxford: Basil Blackwell, 1986) pp.77-94.

${ }^{10}$ Sharon L. Jansen, Political Protest and Prophecy under Henry VIII (Woodbridge: Boydell Press, 1991) p.154.

${ }^{11}$ Keith Thomas, Religion and the Decline of Magic (London: Penguin, 1971) pp.469, 502-3.
} 
Thomas believed that prophetic belief declined during the eighteenth century as part of a general turning away from "non-rational" beliefs. In 2006 Tim Thornton disputed this "modernization narrative," arguing instead for "a strong continuity in nonrational elements to the political culture" of England. ${ }^{12}$ Thornton analysed the Nixon and Mother Shipton prophetic traditions throughout the seventeenth, eighteenth, and nineteenth centuries, contending that their popularity was determined more by the usefulness of their language to current political and social issues than the challenge of rationalism. Thornton prefaced his main argument with a chapter on prophecy in the sixteenth century, which emphasised the importance of prophecy to the politics of the court. While the majority of historiography on prophecy in the early modern period has treated it as "the language of the excluded and oppressed," Thornton demonstrated how prophetic belief permeated the regime itself, including such important figures as Thomas Cromwell and Anne Boleyn. ${ }^{13}$ Most of the supportive evidence Thornton uses, however, is from Henry VIII's reign. He devoted only four pages to Elizabeth's reign; two giving examples of prophetic activity in rebellions against her rule, and two concerning the usage of Thomas of Erceldoun's prophecies in relation to Mary Queen of Scots. ${ }^{14}$

The only full length study of political prophecy in England to concentrate on Elizabeth's reign is Howard Dobin's Merlin's Disciples, published in 1990. Dobin focused on the literary manifestations of the native British tradition of political prophecy, relying on published material such as The Mirror for Magistrates and Edmund Spenser's The Faerie Queene. Dobin argued that prophecy was an inherently destabilising force in sixteenth-century England and that any "attempt to fix prophetic meaning in support of the crown" was "doomed to failure" due to the "plurality of prophetic signification." 15

Dobin's work, while valuable, is limited by its reliance on literary sources. To gain a full understanding of the role of prophecy in the political landscape of England under Elizabeth I, one needs to acknowledge that prophecies were not only written, but also spoken. Indeed, legal restrictions on publication meant that prophecies with political implications circulated primarily by rumour or in manuscript. While this means that prophetic activity left little direct evidence, we can reconstruct numerous examples through references contained in assize records, Privy Council reports, depositions,

\footnotetext{
${ }^{12}$ Tim Thornton, Prophecy, Politics and the People in Early Modern England (Woodbridge: Boydell Press, 2006) pp.9-11, 194.

${ }^{13}$ Ibid., p.32.

${ }^{14}$ Ibid., pp.24-5; 48-9.

${ }^{15}$ Howard Dobin, Merlin's Disciples: Prophecy, Poetry, and Power in Renaissance England (Stanford: Stanford University Press, 1990) p.135.
} 
diplomatic and administrative correspondence, and other records. David Cressy's study of treasonable speech, Dangerous Talk, showed how studying the "redactions, quotations, and representations" of spoken language contained within the historical record can expose the everyday politics of early modern England. ${ }^{16}$ While Sharon Jensen's Prophecy and Protest and Tim Thornton's Prophecy and the People have done this for the reign of Henry VIII, there is yet to be a similar survey for Elizabeth's reign.

\section{Prophetic Belief in Elizabethan England}

Political prophecies were prolific in Elizabethan England. During his trial in 1572 the Duke of Norfolk admitted that he had seen "above sixty," and in 1588, being then in his mid-twenties, John Harvey claimed to have read or heard a similar number. ${ }^{17}$ Men and women from all social classes discussed and distributed prophecies. Prophetic knowledge could derive from a variety of sources, including astrological prognostication, direct revelation from God, communication with spirits or demons, interpretation of scripture, and the prophecies attributed to legendary figures such as Merlin. While these have often been treated separately in histories of prophecy, in practice political prophecies often drew on multiple traditions. The validity of any particular prediction gained strength if it was supported by more than one source of knowledge.

The British tradition of Galfridian prophecy retained its prestige into the Elizabethan era. Merlin remained the most popular figure to whom such prophecies were ascribed. Edward Topsell complained in a sermon published in 1599 that "aboue all the simple and vulgar people imagine that there is no Scripture like to Merlins prophesie," and in 1600 Lodovic Lloyd wrote to Sir Robert Cecil that "the old Romanes were not so addicted unto their Sybills, the Egyptians unto the priests of Memphis, nor the Frenchmen unto their superstitious Druides, as many in my country [Wales] ar geaven to the prophecies of Merlin."18 Other figures with prophetic authority included the fourteenth

\footnotetext{
${ }^{16}$ Adam Fox, 'Rumour, News and Popular Political Opinion in Elizabethan and Early Stuart England', The Historical Journal, Vol. 40, no.3, September 1997, pp.597-620; David Cressy, Dangerous Talk:

Scandalous, Seditious, and Treasonable Speech in Pre-modern England (Oxford: Oxford University Press, 2010) p.ix.

${ }^{17}$ CP 6/21; John Harvey, A Discovrsive Probleme concerning Prophesies, How far they are to be valued, or credited, according to the surest rules, and directions in Divinitie, Philosophie, Astrologie, and other learning (London, 1588) p.3.

${ }^{18}$ Edward Topsell, Times Lamentation (London, 1599) p.63; CP 250/7.
} 
century Scottish prophet Thomas of Erceldoune and medieval saints such as Bede and John of Bridlington. ${ }^{19}$

Another respected method for predicting the future was astrology. The idea that the movement of celestial bodies influenced events on earth was a fundamental aspect of the early modern worldview, though theologians debated the extent to which this included human behaviour. Almanacs, one of the most popular publications of the Elizabethan era, were consulted by people for guidance in their daily lives, including matters such as the best time to administer medical treatment or plant and sow crops. Almanacs generally avoided discussion of political matters, but there were significant exceptions, as we shall see. Astrologers also offered private services such as the casting of nativities and giving advice on the best time to take certain actions. ${ }^{20}$

God remained the ultimate source of authority, and astrology was defended in these terms, "not as though the starres... without their first cause, can bring any thing to passe, but because in their gouernment... they represent before our eyes, the immeasurable wisedome, and eternall prouidence of God."21 Some Elizabethans claimed to have received prophetic knowledge from God directly in the form of dreams or visions. While the Protestant clergy often argued that the age of prophecy had ended, this was by no means a universal position. ${ }^{22}$ The indisputable source of God's word was of course the Bible, and there was an upsurge of interest in Elizabethan England in the prophecies of Daniel and Revelation, which contributed to an outburst of apocalypticism. ${ }^{23}$

*

This thesis is divided into three chapters. The first chapter discusses the political role of prophecy in the period from Elizabeth's accession in November 1558 to the Duke of Norfolk's execution in 1572. The second chapter traces prophecy's role from then to the defeat of the Spanish Armada in 1588. The third chapter examines the turbulent period

\footnotetext{
${ }^{19}$ David Laing (ed.), Collection of ancient Scottish prophecies, in alliterative verse (Edinburgh: Ballayntyne \& Co., 1833).

${ }^{20}$ For a discussion of the almanac trade in early modern England see Bernard Capp, Astrology and the Popular Press: English Almanacs, 1500-1800 (Boston: Faber, 1979). On astrology more generally see Thomas, chs.10-12.

${ }^{21}$ Sheltco à Geveren, Of the ende of this world, and seconde commyng of Christ, a comfortable and necessary Discourse, for these miserable and daungerous dayes, trans. Thomas Rogers (London, 1577) sig.H3r.

${ }^{22}$ Thomas, pp.151-4; Alexandra Walsham, Providence in Early Modern England (Oxford: Oxford University Press, 1999) p.206-7.

${ }^{23}$ See Richard Bauckham, Tudor Apocalypse: Sixteenth Century Apocalypticism, Millennarianism, and the English Revolution (Appleford: Sutton Courtenay Press, 1978); Katherine R. Firth, The Apocalyptic Tradition in Reformation Britain, 1530-1645 (Oxford: Oxford University Press, 1979).
} 
which followed until Elizabeth's death in 1603 and the succession of James I. Together these chapters will reveal how prophecies played a central role in matters of state throughout the whole of Elizabeth's reign, whether prompted by international conflicts, power struggles at Court, religious disputes, economic grievances, or the ever-pressing matter of the succession. 


\section{CHAPTER ONE (1558-1572)}

When Elizabeth ascended to the throne on 17 November 1558 at the age of twenty-five, England's future was extremely uncertain. Elizabeth, the last of Henry VIII's children, came to the throne unmarried and childless. Both her siblings had ruled briefly, and there was no guarantee that Elizabeth's reign would not follow suit. Many assumed that she would marry as soon as possible in order to produce an heir and guarantee the succession, and that her choice of husband would dictate the Religious Settlement and England's place in the international order. The progress of the Reformation in England had been reversed during her half-sister Mary's reign (1553-1558) and while it was certain that Elizabeth would reclaim the supremacy, the extent of her enthusiasm for other reforms remained unclear.

As at other times of uncertainty, Elizabeth's subjects turned to prophecy for guidance and assurance. This chapter will discuss political prophecy during the first fourteen years of Elizabeth's reign, ending with the execution of the Duke of Norfolk in June 1572 following the discovery of his involvement in the Ridolfi Plot to place the Catholic Mary Queen of Scots on the throne. As a competing claimant to the English throne, Mary was the subject of much of the prophecy circulating during this period. The Privy Council, fearing that prophecy could mobilise Mary's supporters, criminalised and demonised prophecy that threatened Elizabeth's rule.

\section{A New Reign}

Elizabeth's supporters used prophecy to endorse her governance. John Dee produced an electionary horoscope of "what in my judgment the ancient astrologers would determine of the election day... as was appointed for her Majestie to be crowned in," which was delivered to the Queen at Robert Dudley's request. ${ }^{24}$ Undoubtedly the horoscope would have predicted a long and prosperous reign, but others were less optimistic about the prospects for the new regime. Nicholas Colman of Norwich, for example, declared in February 1559 that "certain seditious persons... strangers, viz, Scots, Frenchmen, Spaniards and of other foreign nations" would in May, June and July of that year, "set divers market towns and villages on fire," including the City of Norwich. He claimed to

\footnotetext{
24 'The Compendious Rehearsal of John Dee' in John Dee, Autobiographical Tracts, James Crossley (ed.) (Whitefish: Kessinger Publishing, 2003) p.21.
} 
have received this knowledge "by certain visions and dreams that he had in his sleep.",25 In a letter to King Philip II written 29 December 1558 the Spanish ambassador in London, the Count de Feria, remarked that "they are so full of prophecies in this country that nothing happens but they immediately come out with some prophecy that foretold it so many years ago, and it is a fact that serious people and good catholics even take notice of these things and attach more importance to them than they usually merit." The content of these prophecies, he claimed, were "that [Elizabeth] will reign a very short time, and that your Majesty [King Philip] will again reign over the country."26

The Spanish ambassador's letter probably refers to the conjurations of at least five men who tried to predict Elizabeth's fate in the first month of her reign. Only a matter of days after Mary I's death on 17 November 1558, John Prestall, Kele, and Anthony Foretescue, who had served as comptroller to Cardinal Pole, were arrested by the Privy Council. ${ }^{27}$ They had supposedly "cast their figures to calculate the queen's life, and the duration of her government, and the like." ${ }^{28}$ Meanwhile two other men, Richard Parlaben and a tailor named John Thirkle, were also "detected of conjuring" and ordered to be examined. ${ }^{29}$ Despite the Privy Council's nervousness about political prophecies, the lack of any legislation against conjuring made it impossible to punish those caught engaging in such activities, and Fortescue, Kele and Prestall were released on 25 November. ${ }^{30}$ The examinations "of some that practysed conjuring in the Cytie of London" were sent to the Bishop of London on 17 December with instructions for him to "procede by suche severe punishement against them... according to thorder of thecclesyasticall laws," but there is no record that indicates that Bonner took any action against them. ${ }^{31}$ A bill against "Sorceries, Witchcrafts, and Prophecies, of Badges and Arms," which would have granted the civil authorities power in such cases, was introduced privately into the parliament of 1559, but failed to pass before the prorogation of parliament in May of that year. $^{32}$

\footnotetext{
${ }^{25}$ Walter Rye (ed.), Depositions taken before the Mayor and Alderman of Norwich, 1549-67 (Norwich: A. H. Goose, 1905) pp.61-2.

${ }^{26}$ Count de Feria to the King, 29 December 1558, CSP Spanish, Vol. 14, pp.17-18.

${ }^{27}$ TNA PC $2 / 8$ f. 196.

${ }^{28}$ John Strype, Annals of the Reformation and the Establishment of Religion, Vol. 1 (Oxford: Clarendon Press, 1824) pp.9-10.

${ }^{29}$ TNA PC $2 / 8$ f. 198.

${ }^{30}$ TNA PC $2 / 8$ f. 198.

${ }^{31}$ TNA PC $2 / 8$ f.212.

${ }^{32}$ Sir Simonds d'Ewes, The Journals of all the Parliaments during the reign of Queen Elizabeth, Paul Bowes (ed.) (London, 1682) pp.29-30, 53; G. R. Elton, The Parliament of England, 1559-1581 (Cambridge: Cambridge University Press, 1989) p.111.
} 
Political prophecies found a wider audience at the beginning of Elizabeth's reign in published almanacs. Lewes Vaughan's prognostication for 1559, for example, stated that "the Figure of the heavens, at the time of the Eclipse of the Moone... signifieth great mischief, discorde, manslaughter, hatred and wrath, aswel between great princes and ecclesyasticall persons, as the common people." 33 A passage in Latin predicted "rebellion against the monarch, mutations in the affairs of the Crown and accidents befalling the nobility." ${ }^{34}$ Of greatest significance were the prognostications of the French astrologer Nostradamus. His forecast for 1559 was translated into English and warned of great troubles, including "the death, ruyne, affliction and banishement of the enemies" of the Catholic Church, "destruction and ruyne of Sectes, mutations and alterations of kingdoms," and "commotions of warre" with France the supreme victor. ${ }^{35}$ While England is never mentioned specifically, these were dire predictions for the kingdom currently at war with France and under the rule of the Protestant Elizabeth.

Committed Protestants were a minority at the beginning of Elizabeth's reign and Nostradamus's prophecies fostered doubt among many of her subjects about the wisdom of the Religious Settlement. When defending his hesitance in accepting the Archbishopric of Canterbury to Sir Nicholas Bacon, Matthew Parker felt it necessary to assure him "that the prognostication of Mr Michael Nostre Dame" did not "reigneth in my head." $"$ In his tract against astrology published in 1560 William Fulke lamented that "thys Nostradamus reigned here so lyke a tyrant wyth hys south saiynges, that without the good lucke of hys prophesies it was thought that nothing could be brought to effecte." ${ }^{37}$ The next year Francis Coxe decried that "the whole realm was so troubled and so moved with the blinde enigmatical and devilish prophesies of that heaven gaser Nostradamus, in such sort, that even those whiche in their heartes coulde have wished the glory of God

\footnotetext{
${ }^{33}$ Lewes Vaughan, A Newe Almanacke and Prognostication, Collected for the yeare of our Lord God M.D.L.IX. (London, 1559) sig.B8v.

${ }^{34}$ Norman Jones, The Birth of the Elizabethan Age: England in the 1560s (Oxford: Blackwell Publishers, 1996) p.39.

${ }^{35}$ Nostradamus, The Prognostication of maister Michael Nostredamus, Doctour in Phisick. In Prouince for the yeare of our Lorde, 1559 (Antwerp, 1558) sigs.B8r, C2v-C3r.

${ }^{36}$ Dr. Matthew Parker to Sir Nicholas Bacon, 1 March 1559, Lambeth MS 959, no.37, printed in John Bruce and Thomas Thomason Perowne (eds.), Correspondence of Matthew Parker, D.D., Archbishop of Canterbury (Cambridge: Cambridge University Press, 1853) p.59.

${ }^{37}$ William Fulke, Antiprognostication that is to saye, an inuectiue against the vayne and vnprofitable predictions of the astrologians as Nostrodame, \&c. (London, 1560) sig.A8r.
} 
and his worde moste glorishing to be established: were brought into suche an extreme coldnes of faythe, that they doubted Godde hadde forgotten hys promise." 38

\section{Conjuring Priests and Catholic Conspiracy}

Conjuration drew the attention of the authorities again after Father John Coxe was apprehended on 14 April 1561 while attempting to secure passage to Flanders with letters to Catholic exiles. In his examination Coxe admitted that he and a number of other priests had sung Mass in the homes of various Essex gentlemen including Sir Thomas Wharton, Sir Edward Waldegrave, and Lord Hastings of Loughborough, all of whom were prominent courtiers under Mary I. ${ }^{39} \mathrm{He}$ also confessed to the "hallowinge of certeyn coniurations" for Father Leonard Bilson "to obteyne the love of my Ladye Cotton." 40 When the Bishop of London, now Edmund Grindal, sent John Coxe's confession to Elizabeth's Secretary of State Sir William Cecil, he urged that "for this magic and conjurations your honours of the Council must appoint some extraordinary punishment. My Lord Chief Justice saith the corporal law will not meddle with them."41

Among the twenty-two "prisoners for the mass" was Arthur Pole, Anthony Fortescue's brother-in-law and nephew of the recently deceased Archbishop of Canterbury, Cardinal Pole. ${ }^{42}$ According to an anonymous commentator there was "suspicion of some confederacy" between Pole and Lord Hastings of Loughborough, who from 1559 had been subject to Elizabeth's displeasure for "greatly caressing" Pole as a claimant to the throne through his Plantagenet descent. ${ }^{43}$ At the time of his arrest plans were in motion to marry Pole to a sister of the Earl of Northumberland, which would have strengthened his claim, and "many papystes of the southe parte had mente to go thither." This anonymous source also reports that some of those imprisoned "were thought to have coniured to have knowen howe longe the Quene should Reigne, and what should become of Relligion."44 This statement is corroborated by a letter from the Spanish ambassador, now the Bishop de Quadra, to Philip II dated 30 June. The ambassador wrote that, among those sentenced, five or six clergymen had been "degraded... as wizards and

\footnotetext{
${ }^{38}$ Francis Coxe, A short treatise declaring the detestable wickednesse, of magicall sciences, as Necromancie. Coniurations of spirites, Curiouse Astrologie and suche lyke (London, 1561) sig.A5r.

${ }^{39}$ TNA SP $12 / 16$ ff.117r-v.

${ }^{40}$ TNA SP $12 / 16$ f.120r.

${ }^{41}$ TNA SP $12 / 16$ f. $115 \mathrm{r}$.

${ }^{42}$ TNA SP $15 / 11$ f. $10 \mathrm{r}$.

${ }^{43}$ BL MS Add. 48023, f.354v; The Bishop of Aquila to the Count de Feria, 27 December 1559, CSP Spanish, Vol. 14, p.119.

${ }^{44}$ BL MS Add. 48023, f.354.
} 
necromancers" and were found with "calculations of the nativity of the Queen and Lord Robert [Dudley]," implying their involvement in Dudley's attempt to gain Catholic support to marry the Queen, a stratagem opposed by William Cecil. ${ }^{45}$

By creating an association between Catholic worship and the practice of treasonous magic, Cecil encouraged Elizabeth's government to take a stronger stance against Catholics. At the time of the arrests, the papal Nuncio, the Abbot of Martinego, sought entry into England to invite Elizabeth to send representatives to the Council of Trent. Cecil admitted in a letter to Throckmorton that he had thought it "necessary to dull $y^{\mathrm{e}}$ papiste expectation, by discoveryng of certon mass mongars and punishing of them," given the "Romish influence" (through Robert Dudley) towards the admittance of the Nuncio "which by $\mathrm{y}^{\mathrm{e}} \mathrm{Q}$. Ma ${ }^{\text {te }}$ lenyte grew to rank." 46 Thus, one of the arguments put forward against admitting the Nuncio during a consultation held on 1 May 1561 was that "great perills" were "likely to follow if this nuncio shuld be p[er]mitted to come," for even the "noyse or sounde" only of his coming had "wrought in sundry evill disposed psons such a boldenes $\&$ courage... to breake the lawes $\mathrm{w}^{\text {th }}$ great audacite and to disperse abrode faulse and slanderous reportes of the queen $\mathrm{ma}^{\text {tes }}$ disposition to change her religion and the governance of this realme." These persons-evidently those who had been implicated by the capture of Coxe in April—had also "coniured with the devill and cast figures to know the continuance of her ma ${ }^{\text {tes }}$ lief $\&$ reign... and have devysed that the devill shuld in their coniurations make answer that she shuld not long continue., ${ }^{, 47}$

Cecil and his Protestant contemporaries connected international Catholic conspiracy with "the fear of domestic subversion." 48 Thus the Privy Council questioned Lady Waldegrave as to what she knew "of $y^{\mathrm{e}}$ coming of $\mathrm{y}^{\mathrm{e}}$ Pope's nuncio into this realm," as well as "of $\mathrm{y}^{\mathrm{e}} \mathrm{Q}$. ma ${ }^{\text {te }}$ marriage, \& of $\mathrm{y}^{\mathrm{e}}$ succession to $\mathrm{y}^{\mathrm{e}}$ crowne thereof, yf God should not send her ma ${ }^{\text {tie }}$ issue of her body" and where she had "first hear[d] of a crosse being found in a tree in Wales, and who showed you that crosse, or $y^{\mathrm{e}}$ picture of $\mathrm{y}^{\mathrm{e}}$ crosse?"49 This last question refers to the case of another of the prisoners in the Tower, Sir Thomas Stradling, who had commissioned four paintings of an image of a cross which he had

\footnotetext{
${ }^{45}$ Bishop Quadra to the King, 30 June 1561, CSP Spanish, Vol. 14, p. 208.

46 TNA SP 70/26 f.61r; Bishop Quadra to Lord Robert Dudley, 27 April 1561, CSP Spanish, Vol. 14, pp.195-199; Jones, The Birth of the Elizabethan Age, pp.131-2.

${ }^{47}$ TNA SP $70 / 26$ ff. $15 \mathrm{r}-\mathrm{v}$.

${ }^{48}$ Stephen Alford, The Early Elizabethan Polity: William Cecil and the British Succession Crisis, 1558 1569 (Cambridge: Cambridge University Press, 1998) p.54; Norman Jones, 'Defining Superstitions: Treasonous Catholics and the Act against Witchcraft of 1563', in Charles Carlton et. al. (eds.), State, Sovereigns \& Society in Early Modern England (New York: St. Martin’s Press, 1998) p.194.

${ }^{49}$ TNA SP $15 / 11$ f.9r.
} 
found in the stump of an ash tree that had been blown down in a storm on his estate in Glamorganshire in March of 1559. Word of this "miracle of St Donats" spread not only through England but also to Europe after Stradling sent one of the pictures to his daughter in Lorraine. It was interpreted as a sign from heaven prophesying that Catholicism would soon be restored in England. ${ }^{50}$

While the laity were punished in Essex, the priests accused of conjuring were publicly humiliated in London, being pilloried in Westminster on 23 June 1561 and in Cheapside two days later. A copy of Francis Coxe's confession was published by John Awdeley on 7 July and reveals the government's concerns about political prophecy. Coxe condemned a wide range of predictive techniques, describing his fellow priests on the pillory as "some being magicians and astrologians, some necromantians, some witches and sorcerers, some blind prophesyers, [and] some fortune tellers." He claimed to:
now utterly renounce and forsake all such kinds of superstitious curious, wicked and devilish sciences, wherin the name of God is most horribly abused, and society or pact with wicked spirits most detestably practiced, as necromancy, geomancy, and that curious part of astrology wherein is contained the calculating of nativities... with all other the like magics. ${ }^{51}$

The specific content of the conjurors' prophecies was not important; indeed, publicising this would have been dangerous for the government. Rather, Coxe's confession reflects the need to address the threat posed by prophecy more generally. Howard Dobin has described prophecy as "a form of political discourse" in which "the prophet invokes God as the authority superior to... the earthly powers of church and state." $" 52$ By its very nature then, prophecy challenged the absolute sovereignty of the monarch. By not only punishing the priests but also requiring them to publicly declare the falsity of their prophecies and their origin not in God but in the malicious workings of the Devil, the government re-established its authority and condemned their religion.

The Elizabethan regime could not control all interpretation of prophecies, however. Recently Adam Fox has shown how prophecies formed part of a popular

\footnotetext{
${ }^{50}$ TNA SP 15/11 f.18r; SP 12/17 ff.41r-42r; R. A. Griffiths, 'Stradling, Sir Thomas (c. 1498-1571)', ODNB; http://www.oxforddnb.com/view/article/26629; accessed 20 August 2012.

${ }^{51}$ The unfained retraction of Francis Coxe, which he uttered at the pillorye in Chepesyde and els where, according to the councels commaundment (London, 1561), quoted in Jones, 'Defining Superstitions', p.196. ${ }^{52}$ Dobin, p.28.
} 
political discourse in Elizabethan England built on "the oral exchange" of news and information (whether true or false) through "interpersonal contact." 53 It would have been common for prophecies that promised a return to the Catholic faith to be discussed among those who disagreed with the religious direction taken by Elizabeth's regime. Of course, we have no record of such discussions unless they came to the attention of the authorities. In late 1561, for example, William Cecil learned that a Catholic curate in the parish of Newington in London, William Appleforth, had spoken "certayne words agaynste the quenes maiestye." Appleforth wrote to Cecil confessing that he had heard from a man he had passed near St. Bride's church that a "man before your honor to be examined of wordes agaynste the Queen's grace" had said that she would "nott lyve unto chrystmas," and "that the olde lawes shoulde ypp agayne in despyte of all that wolde saye naye." Upon returning home Appleforth had repeated the prophecy to certain other men, along with what he had read in an astrological prognostication of "tempestyous wether death \& syckenes" to come. ${ }^{54}$

Cecil had Appleforth committed to the Gatehouse and, in an effort to track down the source of the rumour, asked that the Bishop of London examine John Hille, the parson of St. Olave's church in Silver Street, whom Appleforth had claimed was in his company when he had heard it. ${ }^{55}$ Hille admitted to having drunk in an alehouse near Fleet Bridge with Appleforth and one John Lintalle, but denied that there was "talk of any newes or other matter towchynge the quenes ma ${ }^{\text {tie }}$ or matter of religion." 56 Appleforth may have lied about the origin of the rumour, but one must wonder why he would mention Hille's name unless he believed that he would corroborate his story, so it seems more likely that Hille lied about their discussion in order to save himself and Lintalle from punishment.

\section{The Succession Claim of Mary Queen of Scots}

The prospect for a return to Catholicism in England was embodied primarily in the person of Mary Queen of Scots and her competing claim to the English throne. In the eyes of the Catholic Church, which had never recognised Henry VIII's marriage to Anne Boleyn, Elizabeth was illegitimate. As a descendent of Henry's elder sister Margaret Tudor, Mary Stuart was therefore the rightful Queen of England. Mary had been raised in the French

\footnotetext{
${ }^{53}$ Adam Fox, 'Rumour, News and Popular Political Opinion in Elizabethan and Early Stuart England', Historical Journal, Vol. 40, no. 3, September 1997, p.620.

${ }^{54}$ TNA SP $15 / 11$ f.78r.

${ }^{55} \mathrm{Ibid}$.

56 TNA SP 12/21 ff.10r-v.
} 
court since she was six and in 1558 married Francis, Dauphin of France. Following Mary I's death in November the Queen of Scots incorporated the arms of England into her coat of arms. France, still at war with England, appealed to the Pope to support her claim, but Philip II of Spain intervened to prevent papal recognition of her legitimacy. ${ }^{57}$

When Mary returned to Scotland in 1561 following her husband's death the previous year her claim to the English throne became a pressing concern for Elizabeth: a "diplomatic and practical problem in Britain rather than a theoretical and distant rallying point," as Stephen Alford has described it. ${ }^{58}$ It is not surprising, then, that at this critical point Mary emerged as the subject of political prophesying. On 9 August 1561 Thomas Randolph informed William Cecil that the Earl of Huntly's wife, Lady Elizabeth Keith, had consulted with her "familiars" concerning Mary's return to Scotland, and that they had promised her "that the Quene shall never set her foote in Scottyshe grounds." If this information turned out to be false, Randolph wrote, he "would she were burned for a witch." ${ }^{\prime 59}$ Another letter from Randolph to Cecil, sent on 24 September, reported that during Mary's stay at Stirling Castle a fire had taken while she slept, and that "those who speak of prophecies" took this to be the fulfilment of "an old one... that a Quene sholde be burnte at Sterlinge." 60

Prophecies concerning the Queen of Scots' succession to the throne of England proved most threatening to Elizabeth. One of the reasons Elizabeth refused to name a successor was her fear that if there was "any heire apparente knowne the people would be more affectionated to him than to her... And that the people in hearing never so lytell faulte in the prince woulde yf the successor were knowne, exaggerat yt."61 Prophecies that named her successor, if believed, could have the same effect. Thus, when Elizabeth heard that the Countess of Lennox, Lady Margaret Douglas, had openly declared that Mary would marry her son, Lord Darnley, and that they would rule England together, she summoned the family to London, had the Earl of Lennox imprisoned in the Tower, and ordered Margaret and two of her children to be held in the custody of Sir Richard and Lady Sackville at Sheen. ${ }^{62}$ According to the articles laid against her, Lady Douglas had claimed that it had been prophesied when her first son died in 1545 that her next son

\footnotetext{
${ }^{57}$ BL MS Cotton Caligula BX f.18r; Judith M. Richards, Elizabeth I (London: Routledge, 2012) p.55.

${ }^{58}$ Alford, The Early Elizabethan Polity, p.88.

${ }^{59}$ BL MS Cotton Caligula BX f.39v.

${ }^{60}$ BL MS Cotton Caligula BX f.186r.

${ }^{61}$ BL MS Add. 48023, f.362r.

${ }^{62}$ Rosalind K. Marshall, 'Douglas, Lady Margaret, countess of Lennox (1515-1578)', ODNB; http://www.oxforddnb.com/view/article/7911; accessed 5 June 2012.
} 
would be king of both England and Scotland. Further, it was alleged that "by mediate persons she uses witches and soothsayers, and has one within her house, who told her when Nesbit was in the Tower last, that the same should not be her trouble, but that she should have a greater, and do full well.",63

Elizabeth hoped to resolve the issue of Mary's claim to the throne of England through a meeting of the two Queens. It was intended that Mary would recognise Elizabeth's right to the English throne during her lifetime in exchange for Elizabeth acknowledging her as heir apparent. One of those involved in negotiating the meeting was Sir Robert Melville. According to the memoirs of his brother James, at some time in 1561 Robert was approached by "ane Bassentin a Scottis man," who told him that "all your vprycht dealing and your honest trauell wilbe in vain" for the two Queens would "neuer meit togither, and nyxt ther will neuer be bot discembling and secret hattrent for a whyll, and at lenth captyiute and vtter wrak for our Quen be England." He further prophesied that "the kingdome of England sall of rycht fall to the crown of Scotland... Bot alace it will coist many ther lyues, and many bludy battailes wilbe fochten first," of which the Spanish would take part, "and will tak a part to themselues for ther labours, quhilk they wilbe laith to leaue again."64

Sir Robert refused to credit such "deuelisch newes," which he criticised as "false vngodly and vnlawfull for Christiens to medle... with." He believed that such knowledge only could have been gained through consorting with demons. Bassantin denied having "cast [him]self in any of the vnlawfull artis that ye mean," saying that he had only used his knowledge of "the naturell scyences, that ar laufull and daily red in dyuers Christien vniversities," meaning astrology. ${ }^{65}$ James Bassantin had studied at the University of Glasgow before travelling to the Continent to further his knowledge of mathematics and astronomy, in which he acquired a "high reputation."66 He defended his predictions by appealing to the authority of the Protestant theologian Melancthon, who had promoted astrology with the belief that it was directly linked to God's providence.

\footnotetext{
${ }^{63}$ TNA SP $12 / 23$ ff. $11 \mathrm{v}, 13 \mathrm{v}$.

${ }^{64}$ Melville, Memoirs, pp.202-3.

${ }^{65}$ Ibid.

${ }^{66}$ A. J. Turner, 'Bassantin, James (d. 1568)', ODNB; http://www.oxforddnb.com/view/article/1632; accessed 13 June 2012.
} 


\section{The Pole Conspiracy and the Criminalisation of Prophecy}

Given the danger that prophecies could pose to Elizabethan authorities, the Privy Council determined to create legal restrictions over their dissemination. Such legislation would not be without precedent, as acts criminalising political prophecy had been passed by both Henry VIII in 1542 and Edward VI in 1550. ${ }^{67}$ The discovery of Arthur Pole's plot in late 1562 to overthrow the Queen utilising prophecy provided the impetus for the successful passage of an Elizabethan version of these acts in the parliament of 1563.

In October 1562 Arthur Pole was arrested along with his brother Edmund Pole, Anthony Fortescue, and two other men as they were about to depart for Flanders. The group had allegedly planned to offer Edmund in marriage to the Queen of Scots in order to obtain aid from the House of Guise. With an army of five thousand supplied by the Guise they intended to invade England through Wales "and to move the subjects to ryse and rebell against the queene, and to make the sayd Skottyshe queen, queen of this realme, and to depose our sovereign ladye" Elizabeth. John Prestall and Edward Cosyn were also implicated in this plot and had invoked "a wicked sprite, and demaunded of him the best waye to bring all their treasons to passe." 68 This conjuration had led them to believe that Elizabeth "should not lyve passinge the nexte spring," thus the group attempted to defend their plans by claiming that "they ment to attempte nothing in the Quene's life tyme."

The Privy Council believed that Arthur Pole's plot had been "formented and managed" by the French and Spanish ambassadors in England. ${ }^{70}$ Arthur Pole had indeed appealed to the ambassadors for assistance: the Bishop de Quadra told the Spanish king that Pole was "determined to leave England on pretext of religion, but the truth is that he is going to try his fortune and pretend to the crown with the help of the Catholics here." Pole had offered himself "with a dozen gentlemen of high position" to serve the king and requested assistance to leave England, which the ambassador had refused. Quadra wrote that Pole had then submitted a similar request to the French ambassador, offering "himself for the present war" there, but was advised "not to go to France... [as] the Guises through their connexion with the queen of Scotland would not like to see another

\footnotetext{
${ }^{67} 33$ Hen. VIII, c.14; 4 Edw. VI, c. 15.

${ }^{68}$ Strype, Annals of the Reformation, Vol. 1, pp.555-7.

${ }^{69}$ BL MS Lansdowne Vol/102 f.25r; MS Cotton Galba C/I f.88v.

${ }^{70}$ Strype, Annals of the Reformation, Vol. 1, pp.557-8; Bishop Quadra to the King, 10 January 1563, CSP Spanish, pp.277-8.
} 
pretender to the English throne." ${ }^{, 71}$ Anthony Fortescue claimed in his confession that "about a month before his apprehension he was with the [French] Ambassador," who had "promised him and his company his letters in their favour when they arrived in Flanders" and had also told him that the "Guise would never assent to set up any other state in this realm than the Queen of Scots, whom he meant to set up as Queen of England."72

The discovery of the Pole conspiracy helped to shape the agenda for the parliament in January 1563. The Commons' petition to the Queen urging her to marry and to settle the succession, read to the House by Thomas Norton on 26 January, referred to the Poles' plans: "We have heard of some subjects of this land... [who] not only hope of the woeful day of your death, but also lay in wait to advance some title.,"73 The 1563 parliament also saw the renewal and passage of legislation against prophesying and conjuring in the "Act against fonde and phantasticall Prophesyes" and the "Act against Conjuracons Inchantmentes and Witchecraftes." 74 Norman Jones has argued that these two acts "were given point and purpose by all the events surrounding the Waldegrave conspiracy," but the timing indicates that the Pole conspiracy had a much more direct influence. $^{75}$ The trial of the conspirators occurred on 26 February at Westminster Hall, within the palace where these two bills were read by the Lords and Commons the next month. $^{76}$

The 1563 "Act agaynst fonde and phantasticall Prophesyes" was modelled on the statute of the same name passed during the reign of Edward VI. The preamble stated that since the expiration of this statute "divers evill disposed psons... have byn the more bolde tattempte the... fayning imagining inventing and publishing of suche fonde and fantasticall Prophesies, aswell concerning the Quenes $\mathrm{Ma}^{\text {tie }}$ as divers honourable Parsonagies Gentlemen and others of this Realme," indicating that not only the Queen but also her councillors had been the subjects of prophesying. The act specifically targeted anyone who:

advisedly and directly advance publishe and set fourthe by Writing Prynting Synging, or any other open Speache or Dede, to any pson or psons, any fonde fantasticall or false Prophecye upon or by thoccasion of any Armes Fieldes Beastes Badges or suche

\footnotetext{
${ }^{71}$ Bishop Quadra to the King, 15 September 1562, CSP Spanish, Vol. 14, pp.259-60.

${ }^{72}$ TNA SP 70/44 ff.14r-v.

${ }^{73}$ TNA SP $12 / 27$ f.140r.

745 Eliz., c. $15,16$.

75 Jones, 'Defining Superstitions', p.200.

${ }^{76}$ BL MS Cotton Galba C/I f.88v; d'Ewes, Journals of all the Parliaments, pp.71, 88.
} 
other lyke thinges accustomed in Armes Cognisaunces or Signettes, or upon or be reason of any Time Yere or Daye name Blodshed or Warre, to thintent therby to make anye Rebellion Insurrection Dissention losse of Lief or other Disturbance $\mathrm{w}^{\text {th }}$ in this Realme and other the Quenes Dominions.

The Act punished offenders with one year's imprisonment and a fine of ten pounds. A second offence would result in life imprisonment and the forfeiture of all one's goods to the crown. ${ }^{77}$

In spite of this punitive legislation, prophecies of Elizabeth's imminent death continued to circulate. In August 1564 the new Spanish ambassador, Guzman de Silva, alluded to "the prophecies that are current about her short life."78 Four months later John Veall, Jone Stamforde, and the parson Edmonde Cowper, following a period of imprisonment in the Tower, were pilloried in Reading on a market day "for forging of false propheties." They were to be freed only "if they shall shew themselfes soroufull for their offences." The parson, being "knowen by reporte of him and others... [to] hathe ben alwaies well given," was to be appointed "to make sum declaracion to the people to beware of suche vaine and fantasticall vanyties."79 Again the pillory became an important site for reasserting the government's control over the future and Cowper, having the most public influence due to his position as parson, was co-opted to serve this aim.

\section{Prophecies Concerning the Marriages of Mary Queen of Scots}

Bassantin turned out to be correct about the prospects of Mary and Elizabeth reaching an agreement, as Huguenot sufferings in France's first War of Religion prevented their meeting from going ahead. The unresolved succession problems between England and Scotland continued to inspire prophetic activity, with the Earl of Bedford reporting in April 1565 that "there was one in hold in Scotlande for prophesying that ther should be some byckering betweene bothe the Realmes." ${ }^{~} 80$ Elizabeth now planned to marry Mary to an English Protestant, specifically Robert Dudley, whom she ennobled Earl of Leicester to enable the marriage to occur. Elizabeth hoped that such a marriage would

\footnotetext{
775 Eliz., c. 15 .

${ }^{78}$ Guzmen de Silva to the King, 12 August 1564, CSP Spanish, Vol. 14, p.374.

${ }^{79}$ TNA PC $2 / 9$ f. 135.

${ }^{80}$ TNA SP $59 / 9$ f.53v.
} 
"neutralize [Mary's] political effect as the single and sovereign power in Scotland," but this plan too failed, and on 29 July 1565 Mary instead married Lord Darnley. ${ }^{81}$

We have seen that Lord Darnley's mother had long promoted her son's royal marriage on the basis of prophecy, and there is evidence that Mary Queen of Scots too may have been influenced by prophecies. William Harrison believed that the marriage had been hastened by "witches and sorcerers... who said that if it were dispatched before July expired it should prove an happy coniunction." The witches claimed that Elizabeth's consent was unnecessary for she would be "a dead woman... before the last of July." 82 Such accusations could well have been invented by Cecil to defame Mary, but considering her years in the household of Catherine de Medici, who is well-known for her occult beliefs, it is not improbable that she might have trusted in such predictions. ${ }^{83}$

English observers continued to claim that Mary patronised seers and prophets throughout the late 1560s. On 5 November 1565 the Earl of Bedford wrote to Elizabeth that Mary was "not only content to continue her evil speech of her... but also gives ear to blind prophecies, tending much to her dishonor." 84 An earlier letter to William Cecil named the source of these as "Trumbull the prophecier." 85 Christopher Rooksby, whom Cecil had planted in Mary's court in May 1566, claimed after his release two years later that Mary had said to him that "the Sothesayers tells us that the Quene of Ingland shall not lyve thre Yere." ${ }^{86}$ Cecil used this allegation in parliament in 1572 to smear Mary in an attempt to convince Elizabeth to execute her. ${ }^{87}$

On 24 June 1566 Mary gave birth to a son, the future James VI of Scotland, who was immediately the subject of prophetic expectation. Four years earlier, in his New Year's Gift to Mary, the Scottish poet Alexander Scott had spoken of a prophecy which he believed meant that her son would come to rule all of Britain:

\footnotetext{
Giffe sawis be suth to schwa thy selsitude,

Quhat berne sould bruke all Bretene be pe see?

The prophecie expreslie dois conclude

The Frensch wife of pe Brucis blude suld be:
}

\footnotetext{
${ }^{81}$ Alford, The Early Elizabethan Polity, p.122.

${ }^{82}$ BL MS Add. 70984, fo.255r, quoted in Glyn Parry, 'The Monarchical Republic and Magic: William Cecil and The Exclusion of Mary Queen of Scots', Reformation, Vol. 17, 2012, p.41.

${ }^{83}$ Parry, 'The Monarchical Republic and Magic', p.34.

${ }^{84}$ TNA SP 59/10 f.168v.

${ }^{85}$ TNA SP 59/10 f.159r.

${ }^{86} \mathrm{CP} 155 / 31$.

${ }^{87}$ T. E. Hartley (ed.), Proceedings in the Parliaments of Elizabeth I, Vol. 1 (Leicester: Leicester University Press, 1981) pp.320, 346.
} 
Thow art be lyne fra him pe nynte degree,

And wes King Frances pairty maik and peir;

So be discence pe sarne sowld spring of pe,

By grace of God, agane pis gude new zeir. ${ }^{88}$

At James's baptism at Stirling in December prophecy was recited which predicted prosperous reigns for both Mary and James and the union of England and Scotland under James. Mary would "resume the sovereignty established by the virtue of her ancestors and for many years" would "reign successfully." James would then "extend the territory of your realm, until the Britons, having finished with war, will learn at last to unite in one kingdom."

In 1567 Mary's widowhood and subsequent remarriage led to her deposition as Queen of Scotland. On 10 February Lord Darnley was found dead in the garden of Kirk o' Field in Edinburgh where he was recovering from an illness. It was suspected that he had been murdered by Lord Bothwell, with whom Mary was married soon after, on 15 May. As with her marriage to Lord Darnley, the date was alleged to have been determined by "wycchys and sorserers." 90 On 20 May Sir William Drury wrote to Cecil that "there ys a wyche in the northe land that affermes the queen shall have yet to come two husbandes more" and that "in the fifth husband's time she shall be burnt." marriage to Bothwell was the last straw for Mary's domestic opponents, who quickly imprisoned her in Lochleven Castle. Near the end of July she was forced to abdicate her throne and her son James was crowned King of Scotland, with the Earl of Moray, her illegitimate half-brother James Stuart, serving as regent. Mary escaped on 2 May 1568 and raised an army to challenge Moray, but was defeated at the Battle of Langside and fled into England.

Mary's presence in England increased the risk she posed as a rallying point for English Catholics, and so Elizabeth placed her under the guardianship of the staunch Protestant Francis Knollys. ${ }^{92}$ In September 1568 Knollys ordered the apprehension of the "notorious papist" Dr Marshall. Marshall was accused of having "used coniurations and

\footnotetext{
${ }^{88}$ James Cranstoun (ed.), The Poems of Alexander Scott (Edinburgh: William Blackwood and Sons, 1896) p.7.

${ }^{89}$ Michael Lynch, 'Queen Mary’s Triumph: The Baptismal Celebrations at Stirling in December 1566', Scottish Historical Review, Vol. 69, no. 187, April 1990, p.13.

${ }^{90}$ TNA SP 59/13 f.88v.

${ }^{91}$ TNA SP 59/13 f.104r.

${ }^{92}$ Wallace T. MacCaffrey, 'Knollys, Sir Francis (1511/12-1596)', ODNB; http://www.oxforddnb.com/view/article/15755; accessed 3 Sept 2012.
} 
casting of figures," which he denied, though Knollys claimed that "dyvers in this countrye, and some of good countenance hathe had a greate opinion of him in that behalf." Among the books found in his possession was one in Latin that when "speakinge of England, amongst many superstitions... mention[ed] that Merlion was a prophet." 93 Whether or not Marshall was truly involved in prophesying for the Catholic cause, such a possibility obviously concerned Knollys. The government was wary of the effect prophecies could have in encouraging rebellion-before the royal judges left for the assize circuits in early 1565, the Lord Keeper Bacon had reminded them that most insurrections began with false prophecies-and Mary's presence in England only increased the risk. ${ }^{94}$

Not all prophecies circulating in the late 1560s favoured Mary, however. In 1569 William Stewart claimed that there was one who had "foretold so many true things" including the murder of Lord Darnley in 1567, the Earl of Bothwell's forfeiture, and Moray's victory at the Battle of Langside. ${ }^{95}$ A prophecy in Cecil's papers dating from 1568 predicted an unhappy death for the Queen of Scots within a short time of her attaining prosperity as well as serious illness and bad treatment for her son. It claimed that the Regent Moray would be thrice victorious in battle but should beware a fourth victory. ${ }^{96}$ Cecil also possessed a nativity of Queen Elizabeth, written in his own hand, which stated that though she had "not much inclination to marriage" she would marry a foreigner "after much counsel taken, and the common rumour of it everywhere, and after very great disputes and arguments concerning it for many years." She would have a son "that should be strong, famous, and happy in his mature age" as well as one daughter. ${ }^{97}$ Elizabeth's marriage and the settlement of the succession, as always, greatly concerned her councillors. The birth of Mary's son in 1566 and Elizabeth's own advancing age increased the instability of the regime, so it is not surprising that Cecil consulted astrology concerning the possibility of their resolution.

\section{Prophecy, Treason and the Duke of Norfolk}

The role of political prophecy in seditious and treasonable activity peaked during the years 1569 to 1571 , when prophecies were employed in various schemes involving the

\footnotetext{
93 TNA SP 53/1 ff.60r-v.

${ }^{94}$ Jones, The Birth of the Elizabethan Age, p.47.

${ }^{95}$ William Stewart to Regent Murray, 5 August 1569, CSP Scotland, Vol. 2, p.665.

${ }^{96}$ CP 98/178.

${ }^{97}$ John Strype, Annals of the reformation and the establishment of religion, Vol. 2, pt.1 (Oxford: Clarendon Press, 1824) p.23.
} 
marriage of Mary Queen of Scots to the Duke of Norfolk, Thomas Howard. Initially a number of Privy Councillors, including Sir Nicholas Throckmorton and the earls of Leicester, Pembroke, and Arundel, supported the marriage, viewing it as a "dynastic solution to the British problem," similar to Elizabeth's earlier plan to marry Mary to Leicester. $^{98}$ Catholic nobles in northern England also voiced their support, believing that the marriage would be advantageous to the survival of their faith. ${ }^{99}$ Elizabeth, however, rejected the proposal, making further negotiations treasonable, and Norfolk's continued involvement in efforts to see the marriage through led to his execution on 2 June 1572.

Prophecies relating to the prospective union of Mary and Norfolk were circulating as early as May 1569. That month the leaders of an enclosure riot in Chinley, Derbyshire were questioned as to whether they did "confederate, consulte, practice, or otherwise confer and talk with one Mr. Bircles of the countye of Chester... touching or concerning prophesies by noblemen, or otherwise, and what books of prophesie have you or the said Bircles seen or heard, and what is the effect thereof...?"100 In September 1569 Lord Wentworth reported that Richard Cavendish, who had carried Leicester's proposal to Mary in May that she would be restored to the Scottish throne following her marriage to Norfolk, had claimed "that it is concluded by Astronomy that the Scotish Damsell shalbe Quen, and the Duke the Husband."101

Elizabeth, fearful that the marriage might encourage her enemies to rise against her, demanded that Norfolk abandon the plans. He withdrew from court but Elizabeth ordered him back and on 8 October committed him to the Tower. Before his imprisonment Norfolk sent a letter to the northern earls urging them not to rebel "for if they did, it should cost him his head." 102 Nonetheless, on 14 November the earls of Northumberland and Westmoreland occupied the cathedral in Durham with a group of their immediate followers and celebrated a Catholic mass. From here they gathered some 6,000 men and marched south. K. J. Kesselring has suggested that the prophetic texts circulating in the north in the months prior to the rebellion served as one of the "tools for

\footnotetext{
${ }^{98}$ Alford, The Early Elizabethan Polity, p.203.

${ }^{99}$ Michael A. R. Graves, 'Howard, Thomas, fourth duke of Norfolk (1538-1572)', ODNB; http://www.oxforddnb.com/view/article/13941; accessed 3 September 2012.

${ }^{100}$ R. H. Tawney, The Agrarian Problem in the Sixteenth Century (New York: Longmans, Green \& Co., 1912) p.329. Keith Thomas suggests that "Mr Bircles" is John Birtles, who was implicated in a conspiracy against the Queen in 1584 and found to possess "a certain old book of prophecy, wherein is great pictures, some with beards." (Thomas, pp.279-80).

${ }^{101}$ CP 156/79; Simon Adams, 'Cavendish, Richard (c.1530-1601)', ODNB; http://www.oxforddnb.com/view/article/4941; accessed 6 August 2012.

${ }^{102}$ Graves, 'Howard, Thomas, fourth duke of Norfolk (1538-1572)'.
} 
honing a critical consciousness" among those who chose to follow the earls. The Council mustered a force of 14,000 in response and the rebellion quickly died out, with the earls fleeing into Scotland. ${ }^{103}$

The defeat of the Northern Rising did not end Elizabeth's troubles, and prophecy continued to encourage those who opposed her. In May 1570 Norwich sheriff Sir John Appleyard, in league with a number of other men including John Throgmorton, George Redman, and Thomas Brooke, attempted to raise a rebellion to overthrow the queen in favour of Norfolk. ${ }^{104}$ A letter to the Countess of Shrewsbury reporting on the trial of the conspirators alleged that they "had set out a proclamation, and had four prophecies," one "touching the wantonness of the Court," another "touching this land to be conquered by the Scots," and two more that the writer could not recall. ${ }^{105}$ The first of these may be the same as a prophecy recorded by Richard Bannatyne that:

The howlat sall leid the beir to his baine.

The court of England, that is so wantoun,

Shall shortlie be brocht to confusioune.

The queine of England sall die the 12 yeir of hir raigne. ${ }^{106}$

On 18 October Thomas Randolph reported that a man had been executed in England for making this prophecy. ${ }^{107}$ He reckoned that he would see many others hanged, "for I know still that this they shoot at, that-fall what may fall-their lion shall be lord of all."108 Randolph had seen these lines on a gift supposedly sent to Mary from the "witches of Athole" which depicted a gentlewoman seated upon a throne and underneath her "a rose, environed with a thissell," representing the union of England and Scotland under Mary, and two lions, Mary and Norfolk, the bigger lion with "his paw vpon the face of the vther, as his lord and commander.",109

Norfolk himself knew of such prophecies, as was revealed following the discovery of the Ridolfi Plot. In August 1571 Thomas Browne informed William Cecil, now Lord

\footnotetext{
${ }^{103}$ K. J. Kesselring, The Northern Rebellion of 1569: Faith, Politics, and Protest in Elizabethan England (Basingstoke: Palgrave Macmillan, 2007) pp.1-2, 44.

${ }^{104}$ Matthew Reynolds, Godly Reformers and their Opponents in Early Modern England: Religion in Norwich, c.1560-1643 (Woodbridge: Boydell Press, 2005) pp.54-5.

105 '_— to the Countess of Shrewsbury', 31 August 1570, in Edmund Lodge (ed.), Illustrations of British History, Vol. 1 (London, 1838) p.513.

${ }^{106}$ Richard Bannatyne, Memorials of Transactions in Scotland, Robert Pitcairn (ed.) (Edinburgh: Bannatyne Club, 1836) p.62.

${ }^{107}$ BL MS Cotton Caligula C/II f.449v.

${ }^{108}$ BL MS Cotton Caligula C/II f.472r.

${ }^{109}$ Bannatyne, p.61.
} 
Burghley, that one of Norfolk's servants, Robert Higford, had attempted to smuggle $£ 600$ in gold coins and two messages in cipher to another servant, Laurence Bannister. Further investigation revealed that these men had conspired with the papal agent Robert Ridolfi, the bishop of Ross and others to have Elizabeth deposed by Spanish forces in favour of Mary and Norfolk. ${ }^{110}$ When Higford was questioned whether "he hath not knowen, or hard that ther wer som in England who travailed by Astronomye, or Art Magick, or such Arts, to understand what should becom of the Scottish Quene, of hir Marriage, or of the Persone that should succeed the Quene's Majestie that now is," he recalled that Norfolk had shown him what he described as "a folishe Prophecye" which began "In exaltation Lunae, Leo succumbet" and ended "Et Leo cum Leone conjungetur, et Catuli eorum regnabunt." 111 The Queen's Serjeant presented this prophecy as serious evidence of Norfolk's treasonous intent at his trial in Westminster Hall on 16 January 1572, translating and interpreting it as follows:

\begin{abstract}
At the exaltation of the Moon (which was the rising of the earl of Northumberland that giveth the moon) the Lion (which is the queen's majesty) shall be overthrown; then shall the Lion be joined with a Lion (which is the duke of Norfolk with the Scottish queen, for they both bear lions in their arms) and their Whelps shall reign (that is, their posterity shall have the kingdom). ${ }^{112}$
\end{abstract}

Norfolk claimed not to remember the prophecy, saying that "he hath hard many foolish Prophecies, which he never estemid, and that no Man more misliked such foolish Prophecyes than he." 113

\footnotetext{
${ }^{110}$ Graves, 'Howard, Thomas, fourth duke of Norfolk (1538-1572)'.

${ }^{111}$ CP $158 / 31$.

112 T. B. Howell (ed.), A Complete Collection of State Trials and Proceedings for High Treason and other Crimes and Misdemeanors (London, 1816) Vol. 1, p.997. This prophecy appears to be derived from "The Cock in the North," the earliest extant version of which originates from the mid-fifteenth century and begins:
}
When the cocke in the Northe hath bilde his nest, And buskith his briddis and becenys hem to fle... Thene shall the mone rise in the northwest, In a clowde of blake as pe bill of a crowe. Then shall pe lion louse the boldest and pe best, pat in brytane was born syne arthers day.

and later states that "pe lion and pe lionasse shall regne is pese." BL MS Cotton Rolls ii.23, printed in R. H. Robbins (ed.), Historical Poems of the XIVth and XVth Centuries (New York: Columbia University Press, 1959) pp.115-7. Versions of this prophecy appear throughout the sixteenth century, adapted to fit the contemporary political circumstances, for example in 1537 (SP 1/127 ff.51r-54v) and 1546 (SP 1/220 f.58r). ${ }^{113}$ CP 6/21. 
Whether or not Norfolk himself was convinced by prophecies which promised his success, they evidently played a part in the scheme and the investigators took their role seriously. Elizabeth herself employed William Wharton to track down "a booke of prophecies" which concerned her, though he was unable to acquire it, and Lewis Evans seized a number of "fonde prophecieing books" in Wales. ${ }^{114}$ The bishop of Ross admitted that Francis Barty, one of those who had carried intelligence between him and the Queen of Scots, had shown him a nativity of Queen Elizabeth in February of 1571, which he claimed to have received from "lerned men in Germanie."115 Laurence Bannister was also questioned as to "what books of prophesies" he had "seen touchynge the late rebellion and the Duke's emprysonement."116 He claimed not to know of any such prophecies, though Edward Elwold of Duston testified the next year that Bannister had asked him "what the prophecies said" of the Duke of Norfolk, to which he had replied that "the hound [Leonard Dacre] should chase the white lion [Norfolk] to Berwick."117

$*$

In A Warning against the dangerous practices of papistes, published in 1569, the prominent parliamentarian Thomas Norton asked "Whense come... the prophesies commonly talked of in the beginning of her most gratious and blessed reigne, how many yeares and how many months her maiesty should continue: Whense came the leude coniurers conference with the devil, how long the Queenes highnesses government and this religion should endure?" His answer was "the same fountayne of treason, whom whense did flow the supplications which the late monster [Stephen] Gardiner penned and preferred in Queene Maries time," that is, papistry. ${ }^{118}$ The Warning was one of a number of pamphlets penned by Norton during this period on behalf of the Privy Council which presented the Northern Rising and attempts to marry Mary and Norfolk as part of a single Catholic conspiracy. ${ }^{119}$ These events, combined with the papal bull of 1570 which declared Elizabeth I a heretic and permitted her subjects' disobedience, marked the end of

\footnotetext{
114 TNA SP 12/83 f.64r; Longleat House DU/II f.53.

${ }^{115}$ BL MS Cotton Caligula C/III ff.208r-v.

${ }^{116} \mathrm{CP} 7 / 4$.

${ }^{117}$ TNA SP 15/21 f.160r. Elwold would have taken this prediction from a prophecy which originated in the mid-fifteenth century known as "The Marvels of Merlin" which tells "Howe a lyon shalbe baneshed and to Berwyke gone.” Bodleian Library MS Rawlison C.813, printed in Jansen, pp.95-7.

118 Thomas Norton, A Warning against the dangerous practices of papistes (London, 1569) sig.H3r.

${ }^{119}$ Michael A. R. Graves, Thomas Norton: The Parliament Man (Oxford: Blackwell Publishers, 1994) pp.113-4.
} 
what Norman Jones has described as a "period of confusion" for Catholics in England. ${ }^{120}$ While the political allegiance of Catholics had not been firmly established in the early part of Elizabeth's reign, after 1570 Catholicism was firmly equated with treason, and belief in false prophecy with both of these.

${ }^{120}$ Jones, Birth of the Elizabethan Age, p.86. 


\section{CHAPTER TWO (1572-1588)}

The Ridolfi Plot of 1571 had seemingly confirmed the danger that Catholic conspiracy posed to the realm, and in the following years the Privy Council intensified surveillance over the Catholic population. At the same time relations between England and the international Catholic powers deteriorated, and in 1588 Philip II launched the Spanish Armada in an attempt to conquer Elizabeth's realm. This chapter will cover the middle years of Elizabeth's reign from the end of 1572 to 1588 , focussing especially on the Privy Council's actions in investigating prophecy during the 1570 s, the investigation of Henry Howard as an example of the role of political prophecy in court politics, the spread of apocalypticism in the early $1580 \mathrm{~s}$, prophecy and popular politics during the $1580 \mathrm{~s}$, and the prophetic expectations that came to surround Philip II and the Spanish Armada.

\section{The Privy Council and Prophecy during the 1570s}

After the discovery of the Ridolfi Plot, the Privy Council was wary of how prophecy might inspire further attempts to overthrow Elizabeth and restore Catholicism to England. They received reports of prophetic activity from both local officials and their own network of spies and informants, such as William Wharton, and took action when they deemed this activity to present a threat. In early 1574 Wharton reported that he knew of some "in the northe parts" who were "evell affected towards her majestie, and that seeke to disturbe the quiet of her Realme," as well as of "certain wrytings and prophesies containing matter against her mate ${ }^{\text {te }}$ person, and tending to the stirringe up of new troubles."121 He sent one such book of prophecies found in the possession of Christopher Metcalf, "the harper's son” of Bainbridge, North Yorkshire, to John Molineux, J.P., who examined Metcalf. ${ }^{122}$ This book "dishonorablie towched ande reprehended... the Quenes ma $^{\text {te }}$ most royall persone ande... estate" and made a discourse "of the acts of the nobilitie of this Realme, and other persons beyond the Seas."123 The Queen took a personal interest in the book and was "desirous to have [it] sent to her."124

Mary Queen of Scots continued to serve as a focal point for the efforts of Catholic dissidents, and in December 1572 the Privy Council ordered the Earl of Shrewsbury, who had taken over guardianship of Mary in 1569, to enquire after John Revell for conjuring

\footnotetext{
${ }^{121}$ TNA SP $15 / 23$ f.116r.

${ }^{122}$ Report by William Wharton, 24 March 1574, CSP Scotland, Vol. 4, p.653.

123 TNA SP $15 / 23$ f.110r.

${ }^{124}$ Report by William Wharton.
} 
in a plot to free her. ${ }^{125}$ Shrewsbury had mentioned Revell in a letter to Lord Burghley sent 11 September 1571 as one who was "well known to be devising and practising against the Queen's majesty's proceeding in religion and her highness' state."126 Revell was successfully apprehended in January 1573 and sent to the Council for examination, along with Thomas Comberford, with whom Revell had resided, and two "masse priests." 127 As part of his investigations Shrewsbury interrogated Avery Keller, servant to Rowland Lacon. He reported to the Council that while Keller had at first pleaded ignorance, after "sharper imprisonment for one night" he had confessed that "he was a dealer with the conjurors; and that he brought certain books of that art unto John Revell." Along with "the conjuring scholars, named Palmer and Falconer, and Skinner, the priest," Revell had "conjured for divers causes," including "to have certain knowledge... touching the state of this realm." 128 This knowledge would have been prophetic in nature and guided Revell in his plans to free Mary. The scholars had also produced charmed plates of gold, which he was to have used to gain Shrewsbury's favour. ${ }^{129}$ Revell was imprisoned in the Tower until March 1574, but there is no record of any of the others being punished. ${ }^{130}$

The Privy Council often had difficulty in tracing prophecies to their source. In May 1576 they ordered Gregory Warner, a gentleman of Broughton in Northamptonshire, to be committed to the Gatehouse for suspicion of the "writing of certaine prophesies which have been founde in his possession."131 Warner denied any knowledge of "how the said books cam into his hands" and insisted that "he had never published nor sped abrode any of them." Merely possessing a prophecy was not a crime under the statute of 1563, so lacking any evidence that Warner had shared the prophecies, the Council released him "upon his owne band... of good behaviour and to be forethecominge at all tymes when he sholde be called." 132

Local officials conducted their own investigations of prophetic activity but often consulted the Privy Council, which made recommendations depending on their judgment of the character of the offender. In February 1579 Arthur Blunte was "accused for having

\footnotetext{
125 TNA SP 53/8 f.164r.

${ }^{126}$ Shrewsbury to Burghley, 11 September 1571, CSP Scotland, Vol. 3, p.694.

${ }^{127}$ BL MS Harley 6991 ff.25r-v.

128 'The Earl of Shrewsbury to the Privy Council', 1 February 1573, in Edmund Lodge (ed.), Illustrations of British History, Vol. 2 (London, 1838) pp.3-4.

${ }^{129}$ BL MS Harley 6991 f.25v.

130 TNA PC 2/10 f.203.

131 TNA PC 2/11 f. 17.

132 TNA PC 2/11 f.21.
} 
in his keeping certaine sedicious prophesies," which he confessed he had received from "one Grene of Lichefield." The Council instructed the Bishop of Lichfield, Thomas Bentham, to examine both men and any "others that shalbe touched with that cause," including Nicholas Nevell. Upon reviewing these examinations and other papers sent to them by Bentham, the Council judged "the whole course of Bluntes lyfe" to be "tending to wickednesse and disceipt," and recommended to the Justices of Shropshire and Staffordshire that he "receve such punishement as by justice his offence hathe deserved." Grene and Nevell, however, being "yong" and "simple" respectively, the Council treated more leniently, leaving it to the discretion of the Justices "to consider of their offences as it shall fall out."133 In January 1580 the Lord Chandos, Giles Brydges, submitted a pamphlet to the Privy Council "containing certen offensive prophesies which... [he had] received from one of his neighboures" in Gloucester. The Council responded by ordering Chandos to "reexamyn his sayd neighboure how he came by the said pamphlette." If the examinate refused to confess, Chandos was "to take bandes of him for his appearance before the Justices of Assises of that countye" or, if he was found to be "evell affected towards the presente state of the Realme," to commit him to prison. ${ }^{134}$

While the records of the Privy Council do not reveal the content of the prophecies that came to their attention, some examples of what were considered seditious prophecies can be found in the assize records and state papers. In February 1573 John Wood, a craftsman from Mayfield, Sussex, was put on trial for having proclaimed at Horsham on 10 May 1572:

\footnotetext{
That this yeare shoulde be greate warres in the northe parte of this Realme and the Scotts shoulde have the upper hande; then the Quene shoulde sende more men, thynkyng theym to be her frynds, but they wylbe her enemyes; the cause whye is this, the Erle of Leicester shall marrye the Quene and then shalbe slayne at London, and the Quenes majestie put from her crowne and dignitie; and a Kynge shall conquerre this lande whose name shalbe Ambrose.
}

Wood was found guilty of seditious words and sentenced to the pillory and one year's imprisonment. ${ }^{135}$ English officials considered as dangerous subjects such as rebellion, who Queen Elizabeth would marry, when she would die, and who would succeed her. In

\footnotetext{
133 TNA PC $2 / 12$ f.397.

134 TNA PC $2 / 12$ f.710.

135 J. S. Cockburn (ed.), Calendar of Assize Records, Sussex Indictments: Elizabeth I (London: Her Majesty's Stationery Office, 1975) p.88.
} 
1574 Richard Jones, the servant of a reputed papist, Richard Owen, was put on the pillory for an hour for saying "there shoulde bee warrs shortely in this lande and that before Michaelmas nexte this lande shoulde bee conquered by straungers and Englishmen and that the oulde religion shoulde bee upp agayne."136

Due to the threat of an alliance between European Catholic powers and English dissidents, the Privy Council also became concerned with the activities of Catholic émigrés overseas. In March 1575 Lord Burghley received a letter from the governor of Portsmouth, Henry Radcliffe, alerting him to "some persones... disorderlie fled owt of this realme" and "their doings sayings and behaviors." A resident of Portsmouth recently returned from Normandy had informed Radcliffe that while discussing the coronation of King Henry III of France a Catholic exile from Devonshire, Robert Crews, had said that there were many in England who believed him to be dead, "but there goeth a prophecye in England that a dead man shall rise that shall make all England to rue yt." Another Englishman replied that "he hoped he shoulde never see that daie," and that neither "he nor all his friends in England... abide by those words." 137 The 'dead man rising' prophecy was a popular one, however, dating back to the fifteenth century and appearing several times throughout the sixteenth. ${ }^{138}$

Catholics often promoted native British prophecies as favouring their cause. A Catholic merchant from Winchelsea, Sussex who was indicted in February 1575 for having said that "he hoped to here or see a masse in Burwisshe churche within a twelvemonthes," was also accused by the minister William Field of repeating a prophecy attributed to Merlin that "When faithe fayleth in pristes sawes and lords hestes ben taken for laws... then let the Lande of Albeon [Britain] loke sone for confucion." "139 In response, Protestant literature increasingly spread the idea that England's Catholics were

\footnotetext{
136 TNA SP $12 / 99$ f.104r.

${ }^{137}$ CP 160/37.

138 Ariel Hessayon, 'Gold Tried in the Fire': The Prophet TheaurauJohn Tany and the English Revolution (Aldershot: Ashgate Publishing, 2007) pp.222-3. It can be traced back to the fifteenth-century prophecy

"The Cock in the North" which contains the lines:
}

Than shall troy vntrew tremble pat dayes,

ffor drede of a dede man when pey here hym speke...

He that is ded and buryed in sight,

Shall ryse agayn, and lyve in lond.

BL MS Cotton Rolls ii.23, printed in Robbins (ed.), Historical Poems, pp.116-7. "Troy untrew" refers to England; according to legend the first king of Britain was a descendent of Aeneas of Troy.

${ }^{139}$ Calendar of Assize Records, Sussex, p.105. A manuscript version of this prophecy is printed in Robbins (ed.), Historical Poems, p.121. 
being misled by the devil's prophecies. A poem by Laurence Ramsay, printed around 1577 , had the devil instructing "his papists" to:

Practise, prate and Coniure, plaie Silvesters part...

Having blinde Prophecies, and whisper in their eare,

That ere long we shall haue, great change of this geare. ${ }^{140}$

These associations contributed to Protestant efforts to demonise Catholicism, presenting Catholics as servants of the devil.

\section{Henry Howard, Prophecy and Court Politics}

Prophecy featured as much in Court politics as it did in discussions among the general populace. Because of their social position, the activities of noblemen posed a greater threat to the realm, but they also had greater means to defend themselves. One of those who drew the state's attention during the middle of Elizabeth's reign was Henry Howard, the younger brother of the late Duke of Norfolk. Howard had himself been suspected of involvement in the Ridolfi Plot in 1571, and in the decade following was part of a group of Catholic gentlemen who promoted the interests of Mary Queen of Scots. ${ }^{141}$

Howard's involvement with this group led to him being investigated regarding a book of pictures which prophesied Queen Elizabeth's successor. On 16 December 1580 the Earl of Oxford, Edward de Vere, publicly confessed to involvement in a Catholic conspiracy with Howard, Charles Arundel, and Francis Southwell, setting off a series of increasingly damning libels. ${ }^{142}$ Oxford must have admitted that they had discussed a prophecy about the Queen, as in his first formal interrogation Arundel was questioned as to what prophecies he had "latelie sene or hard whiche might concerne the contempt, reproche and overthrowe of owre most gracious soverange."143 Arundel confessed that in mid-1579 he had shared with Oxford a prophetic rhyme by one Edward Heywood, but denied having seen any written prophecies. ${ }^{144}$ In a subsequent interrogation Arundel was questioned as to whether Henry Howard had been present when Oxford had "presented a

\footnotetext{
${ }^{140}$ Laurence Ramsay, The practise of the diuell (London, [1577]) sig.B2v.

${ }^{141}$ Pauline Croft, 'Howard, Henry, earl of Northampton (1540-1614)', ODNB; http://www.oxforddnb.com/view/article/13906, accessed 12 Feb 2013; Linda Levy Peck, Northampton: Patronage and Policy at the Court of James I (London: George Allen \& Unwin, 1982) pp.10-11.

${ }^{142}$ This episode and the allegations involved are discussed in detail in Alan H. Nelson, Monstrous Adversary: The Life of Edward de Vere, $17^{\text {th }}$ Earl of Oxford (Liverpool: Liverpool University Press, 2003) pp.203-75 but have not yet been considered in any history of political prophecy.

${ }^{143}$ TNA SP $12 / 151 \mathrm{f} .105 \mathrm{v}$.

144 TNA SP 12/151f.108r.
} 
certayne boke of pictures, after the manner of a prophesie [which] by interpretacion resemblid a crowned sone to the Qwene," that is a male successor. Arundel denied this accusation, claiming that when Oxford had shown him the book he had "coniurid me by soleme othe" not to tell Howard of it, as Oxford thought that Howard would inform Lord Burghley. Nonetheless, when Oxford had been placed under house arrest in 1579 after a dispute with Leicester, Arundel had told Howard "that such a toye Oxford layd vpp in his deske" and that he thought "some man of" Oxford's had "thrust [it] vppon him vnder cullor of a prophesye to cosine him of crownes," for "it was not rare to picke his purse with pretence of novelties and future accidents." ${ }^{145}$ Arundel later attempted to blacken Oxford's reputation further by claiming a more sinister source for the prophecy. He said that Oxford had in fact "paynetid owte" the book himself under the direction of the devil, who he had "often sene... by coniuringe with parsones of the chappell that died," referring to the composer Robert Parsons of the Chapel Royal. ${ }^{146}$

Whether Henry Howard had viewed the book of prophecies was a matter of great concern to the state. As the previous chapter has shown, some Councillors believed that his brother the Duke of Norfolk had been tempted into treason by prophecy earlier in Elizabeth's reign. According to a letter written by Howard to Francis Walsingham in September 1581, "the thing which hir maiestie was wonte to urge against me cheflie was the sight concealement \& construction of a prophecie," of which he denied any knowledge. ${ }^{147}$ Francis Southwell too was questioned as to whether Howard had seen the book. In a letter to Howard he assured him that he "never said yow saw the book of pictures, nor that ever yow gave eny comente of thos figures," but only that Oxford had shown him "the book of pictures... in his gret chamber, and maed me the onli exposition of yt." 148 This statement contradicts Arundel's own assertions that he had been the only one to whom Oxford had shown the prophecy. As Alan H. Nelson has argued, it is likely that all of the conspirators had viewed the book but lied about it to protect Howard. ${ }^{149}$

Treason accusations routinely laboured the point that conspirators against the realm heeded prophecy. In 1580, for example, Vincent Murphyn accused a number of "noblemen and gentlemen," including William Agard and the younger brothers of the Earl of Huntington Sir George and Walter Hastings, of conspiracy to commit treason. He

\footnotetext{
145 TNA SP $12 / 151$ f.98v.

146 TNA SP 12/151 f.103r; Nelson, Monstrous Adversary, p.58.

147 TNA SP $12 / 155$ f.84r.

148 TNA SP $12 / 151 \mathrm{f} .119 \mathrm{r}$.

${ }^{149}$ Nelson, Monstrous Adversary, p.220.
} 
claimed to have been recruited by the conspirators to produce gold by alchemy in order to fund an army which would invade northern England, free Mary Queen of Scots and then march on London. After killing Queen Elizabeth and her Privy Council, Sir George Hastings, who had Plantagenet blood, would marry Mary and claim the throne. George had supposedly shown Murphyn an old book of prophecies which he believed foretold these events and employed him to conjure whether he would survive his brother the Earl of Huntingdon and become King. Upon investigation these allegations were "all proved false and villainous"- the Hastings family was too well connected to suffer conviction and punishment. ${ }^{150}$

Henry Howard often wrote political tracts to gain favour with Elizabeth and her councillors, and it was Oxford's accusations against him which prompted him to write his Defensatiue against the poison of supposed prophesies, published in $1583 .^{151}$ In his dedication, Howard bid Walsingham to "recall the tyme to minde, wherein as well to you, as others of your calling, I engaged my assured promise... to giue publique testimony to the world, what my conceite hath euer beene of Prophecies." ${ }^{252}$ It seems likely that Howard made his "assured promise" in 1581 in order to secure Walsingham's favour. That year, in a letter to Walsingham defending himself against Oxford's charges, Howard had stated that he desired "nothinge more then opportunitie to seale by prouf what I haue already bound by promise." 153

Howard's book attacked numerous forms of prophecy, including "olde paynted books, expositions of dreames, oracles, reuelations, inuocations of damned spirities, [and] judicialles of astrologie." ${ }^{\prime 54} \mathrm{He}$ was particularly critical of prophecy used for political purposes. "The most pestilent and bitter roote" of prophecy, he wrote, is the "curiousitie to search and hunt for deeper knowledge, of the future causes and affaires of the Common wealth: As how long the Prince shall raigne? Who shall succeede and by what meane?" He admitted to having been "acquainted with some godly persons" who were nevertheless "bewitched" by this temptation. ${ }^{155}$ Many of his audience would recognise that these "godly persons" included his brother Norfolk and the Earl of Oxford. Howard referred to

\footnotetext{
${ }^{150}$ BL MS Lansdowne 99 ff.244r-246v; Glyn Parry, The Arch-Conjuror of England: John Dee (New Haven: Yale University Press, 2011) pp.138-40.

${ }^{151}$ Keith Thomas suggested that Howard's "motivation for publication may have been to clear himself from similar imputations" as those which his brother faced at his trial in 1572, but not having examined the manuscripts in SP 12 failed to determine exactly what these were (Thomas, p.480).

${ }^{152}$ Henry Howard, A defensatiue against the poison of supposed prophesies (London, 1583).

153 TNA SP $12 / 155$ f.84r.

${ }^{154}$ Howard, title page.

155 Ibid., sig.E3r.
} 
Oxford's book of prophecy later in the text, writing that "It was once my happe to be examined, vpon the sight of a certayne paynted Treatise... garnished with sundry beastes \& byrds." As in his interrogation, he maintained that he never saw it himself, and that those who did, did not treat it seriously, but rather "made good sport thereat, for a childishe game." 156

Like Thomas Norton and others, Howard asserted that political prophecy was the work of the devil and lamented prophecy's role in fostering religious disunity. He wote that:

\footnotetext{
The deuill hath attempted sundry meanes to disturbe that golden peace which angels wished vnto men, to breede a debate betweene the children of one wombe, that is the members of one church, and the subiects of one gouerment: but yet hath he not bestirred himselfe more gallantly in any one respecte, than by raising vppe certaine busie bodyes in the common wealth, who with limed papers, paynted bookes, \& figures of wild beasts \& birds, carry men from present dueties into future hopes. ${ }^{157}$
}

Unlike Norton, however, because of his own religious tendencies Howard did not associate such activity specifically with Catholics.

Howard's Defensatiue did not improve his position at Court, and soon after its publication the Privy Council arrested him on suspicion of involvement in a plot to murder Elizabeth and crown Mary Queen of Scots as her successor. ${ }^{158}$ William Herle wrote to Burghley that the book was thought "by some of good iudgement to conteyne sundrie heresies and spyces withal of treason," though there is no evidence that the Privy Council took this claim seriously. ${ }^{159}$ The book was more successful later, however; William Covell praised it in the preface to his Polimanteia in 1595, when Howard's career had recovered thanks to the rise of his cousin the Earl of Essex, and a revised edition was printed in 1620, after his political rehabilitation under James I. ${ }^{160}$

\footnotetext{
${ }^{156}$ Ibid., sig.Kk1r.

${ }^{157}$ Ibid., sig.Hh2r.

${ }^{158}$ Croft, 'Howard, Henry, earl of Northampton (1540-1614)'.

${ }^{159}$ BL MS Lansdowne 39 f.193r.

${ }^{160}$ William Covell, Polimanteia, or, the means lawfull and unlawfull, to ivdge of the fall of a commonwealth, against the friuolous and foolish coniectures of this age (London, 1595); Henry Howard, A defensatiue against the poison of supposed prophecies... Now newly reuised (London, 1620).
} 


\section{Apocalypticism and the Great Conjunction of 1583}

The 1570s and 1580s were a high point for apocalyptic expectation in England. Apocalyticism was an integral part of English Protestantism during the Elizabethan era, due in great part to the work of the Marian exiles John Bale and John Foxe, who saw the world's history as a fulfilment of the prophecies of Revelation. They defined the conflict between the Protestant and Roman Catholic churches in terms of the doctrine of the two churches, exacerbating the intensity of religious divisions. Celestial events and natural disasters such as the nova of 1572, the comet of 1577, and the earthquake of 1580 increased public expectation as they were interpreted as signs of the Decay of Nature. ${ }^{161}$ Of particular importance was the conjunction of Saturn and Jupiter predicted for April 1583.

Conjunctions of the two superior planets occurred every twenty years and held varying significance depending on where in the zodiac they occurred. Conjunctions occurring in a new trigon (of which the zodiac was divided into four reflecting the four elements) were considered to be 'greater conjunctions.' The most important conjunctions, like the one predicted for April 1583, occurred at the end of the watery trigon and beginning of the fiery trigon. These rare conjunctions happened every eight hundred years, and believers marked them as "the arrival of a new phase of history." 162

In 1564 the Bohemian astrologer Cyprian Leowitz predicted that the forecast 1583 conjunction would occur when the age of the Earth approached six thousand years, thus presaging the second coming of Christ. The theory that the world would last no more than six thousand years derived from a prophecy in the Talmud, often attributed to the prophet Elias, "that sixe thousand yeares shal the world stand or endure. Two thousand voyde of anye lawe written, two thousand under the lawe written, and two thousand under the dayes of Messias." God would shorten the last millennium, however, for the sake of the Elect. ${ }^{163}$ Leowitz's argument was reinforced further by the prophecy, attributed to the fifteenth century German astrologer Regiomontanus, that 1588 would mark either great upheavals or "an vtter, and final, ouerthrowe, and destruction of the whole world." 164 An English version of this prophecy reads:

\footnotetext{
${ }^{161}$ Richard Bauckham, Tudor Apocalypse: Sixteenth Century Apocalypticism, Millennarianism, and the English Revolution (Appleford: Sutton Courtenay Press, 1978).

${ }^{162}$ Margaret Aston, 'The Fiery Trigon Conjunction: An Elizabethan Astrological Prediction', Isis, Vol. 61, no. 2, Summer 1970, p.161.

${ }^{163}$ Bauckham, pp.166-7.

${ }^{164}$ Richard Harvey, An astrological discourse vpon the great and notable coniunction of the tvvo superior planets, Saturne \& Iupiter, which shall happen the 28 day of April, 1583 (London, 1583) pp.44-5.
} 
When after Chrisets birth there be expirde

Of hundreds fifteen, yeeres, eightie and eight

Then comes the tyme of daungers to be ferde,

And all mankynd with dolors it shall fraight,

For if the world in that yeere doo not fall,

If sea and land then perish ne decaie:

Yet Empires all, and Kingdomes alter shall,

And man to ease himselfe shal haue no way. ${ }^{165}$

Leowitz's book was published in Latin at London in 1573, and the English translation of Sheltco à Geveren's Of the end of this world (1577) included an extract about the conjunction. ${ }^{166}$

Many in England received Leowitz's predictions enthusiastically, and à Geveren's book was reprinted five times before 1588. The translator, clergyman Thomas Rogers, defended the work in 1581 as "both liked of the godlie, allowed of the learned, [and] wel bought-up of al sortes." 167 Two works published early in 1583 repeating Leowtiz's arguments stirred up expectations in England further: Richard Harvey's Astrological Discourse and Robert Tanner's Prognosticall iudgement. ${ }^{168}$ Harvey asserted "that we are most like to haue a new world, by some suddaine, violent, \& wonderful straunge alteration." "169 Both the "common sort of people" and members of the political élite shared these expectations. Protestant theologian William Perkins wrote that "thy song for halfe a yeare was nothing els, but, the coniunction the coniunction," and "the day being come, what staryng was there and gazing into heauen, to see the meeting of those 2. Planets." ${ }^{\prime 10}$ John Dee's drive to reform the calendar was given added urgency by his belief that the dissolution of the world would commence in November 1583, a date affirmed by his conversations with the angels through Edward Kelley. Burghley believed

\footnotetext{
${ }^{165}$ Sheltco à Geveren, Of the ende of this world, and seconde commyng of Christ, a comfortable and necessary Discourse, for these miserable and daungerous dayes, trans. Thomas Rogers (London, 1577) sig.D4r.

${ }^{166}$ Cyprian Leowitz, De coniunctionibus magnis insignioribus superiorum planetarum, solis defectionibus, \& cometis, in quarta monarchia, cum eorundem effectuum historica exposition (London, 1573); à Geveren, sigs.D3r-D4r; Aston, 'The Fiery Trigon Conjunction', p.177.

${ }^{167}$ Thomas Rogers, The general session conteining an apologie of the most comfortable doctrine concerning the ende of this world, and seconde coming of Christ (London, 1581).

${ }^{168}$ Robert Tanner, A prognosticall iudgement of the great coniunction of the two superior planets, Saturne and Iupiter, which shall happen the 8. day of Aprill. 1583 (London, 1583).

${ }^{169}$ Harvey, An astrological discourse, p.38.

${ }^{170}$ William Perkins, Foure great lyers, striuing who shall win the siluer whetstone. Also, a resolvtion to the country-man, prouing it vtterly vnlawfull to buye or vse our yearly Prognostications (London, 1585) sig.B4r.
} 
Dee's conviction, and wrote to Queen Elizabeth that there was "great cause to have this conference accelerated" and that it was "requisite, for a secret matter," for the reform to be put in place "before November."171

Others, however, expressed scepticism that the April 1583 conjunction portended an imminent apocalypse. The astrologer Thomas Heath tried to temper expectations by publishing A manifest and apparent confutation of an astrological discourse in which he argued that Harvey had miscalculated the date of the conjunction, and that it could not "simply of it selfe... forshew any great matter worthy the penning. Much lesse the alteration of kingdoms, the comming of Christe in iudgement, or consummation of the world."172 The Bishop of London, John Aylmer, to whom Richard Harvey had unwisely dedicated his Astrological Discourse, delivered a sermon at Paul's Cross condemning the work. ${ }^{173}$ Aylmer was part of a conservative campaign against radical prophecy led by the Archbishop of Canterbury, John Whitgift, and the Privy Councillor Sir Christopher Hatton. He also preached reassurance at Court against both Galfridian and astrological prophecies which threatened the stability of Elizabeth's regime:

\begin{abstract}
Here is much doubt, saith he, of malum ab Aquilone [evil from the North], and our coleprophets have prophesied that in exaltation Lunce Leo jungetur Leance [at the exaltation of the Moon the Lion (Norfolk) will be joined with the Lioness (Mary)]. The astronomers tell of a watry trigon; that great inundations of waters forshow insurrexions of people, and dounfal of princes: but as long as Virgo [Elizabeth] is the ascendant with us, we need fear of nothing; Deus nobiscum, quis contra nos? [God is with us, who can be against us?] ${ }^{174}$
\end{abstract}

It is notable that Aylmer employs astrological arguments himself in defending the regime's prospects, as Elizabeth's star sign was Virgo, as well as affirming that her authority was granted by God.

The failure of the conjunction to produce any calamitous effects proved the doubters right and fuelled several attacks on prophecy throughout the remainder of the 1580s. Howard's Defensatiue noted "the late offence which grew by most palpable and

\footnotetext{
${ }^{171}$ Parry, Arch-Conjuror of England, pp.151-3; Lansdowne MS 39 f.28r.

172 Thomas Heath, A manifest and apparent confutation of an astrological discourse, lately published to the discomfort (without cause) of the weake and simple sort (London, 1583) sig.D6v.

${ }^{173}$ Millar Maclure, The Paul's Cross Sermons, 1534-1642 (Toronto: University of Toronto Press, 1958) pp.212-3.

${ }^{174}$ Sir John Harington (ed.), Nuga Antiquae: being a miscellaneous collection of original papers in prose and verse (London, 1804) Vol. 2, pp.37-8.
} 
grosse errours in Astrology" in its title, and a ballad entered in the Stationers Register on 3 May 1583 began: "Trust not the conjunctions or Judgementes of men when all that is made shalbe unmade againe." "175 The second part of Phillip Stubbes' Anatomie of Abuses cited the failure of the conjunction to portend any "alteration" as proof of the "vanitie, and vncerteintie" of the astrologers' "curious science."176 William Perkins cited the conjunction in his attack on yearly prognostications, Foure Great Lyers, in 1585, and addressed the 1588 prophecy in A Fruitfull Dialogve in 1587. ${ }^{177}$ John Harvey, who prior to the conjunction had defended his brother's thesis with An astrologicall addition, published A Discovrsive Probleme concerning Prophesies in 1588 in which he condemned "supposed prophesies," especially "the terrible threatenings, and menaces, peremptorily denounced against the kingdoms, and states of the world" for that year. ${ }^{178}$ His dedication to Sir Christopher Hatton makes clear Hatton's role in Harvey's new conservatism. $^{179}$

\section{Prophecy, Sedition and Popular Politics in the 1580s}

When parliament was called in 1581 the strengthening international position of Catholicism together with the arrival of the Jesuit missionaries in 1580 reignited the Privy Council's sense of crisis. They introduced two bills into the House of Lords: one to strengthen the treason laws against the Catholic missionaries and the other against seditious words and rumours. ${ }^{180}$ Included in the "Acte against sedicious Wordes and Rumors uttered againste the Queenes moste excellent Majestie" was a passage which enacted the death penalty for:

any person or persons... [who] by setting or erecting of any Figure or Figures, or by casting of Nativities, or by calculacon, or by any Prophecieng Witchcrafte Cunjuracons or other lyke unlawfull Meanes whatsoever, seeke to knowe, and shall set

\footnotetext{
${ }^{175}$ Virginia F. Stern, Gabriel Harvey: His Life, Marginalia and Library (Oxford: Oxford University Press, 1979) p.70.

${ }^{176}$ Phillip Stubbes, The second part of the anatomie of abuses conteining the display of corruptions (London, 1583) sig.H7r-v.

${ }^{177}$ Perkins, Foure great lyers; William Perkins, The vvorkes of that famous and vvorthy minister of Christ in the Vniuersitie of Cambridge, Mr. William Perkins (London, 1616-18) pp.465-77.

${ }^{178}$ John Harvey, An astrologicall addition, or supplement to be annexed to the late discourse vpon the great coniunction of Saturne, and Iupiter (London, 1583); John Harvey, A Discovrsive Probleme concerning Prophesies, How far they are to be valued, or credited, according to the surest rules, and directions in Divinitie, Philosophie, Astrologie, and other learning (London, 1588).

${ }_{179}$ Parry, Arch-Conjuror of England, p.209.

${ }^{180}$ G. R. Elton, The Parliament of England, 1559-1581 (Cambridge: Cambridge University Press, 1989) p.186.
} 
forth by expresse Wordes Deedes or Writinges, howe longe her $\mathrm{Ma}^{\text {te }}$ shall lyve or contynue, or who shall raigne as King or Queene of this Realme of England after her Highnesse Decease, or else shall advisedlye and with a maliciouse intent againste her Highenes, utter any manner of directe Prophecies to any suche Intent or Purpose, or shall malitiouslye by and Wordes Writing or Printing wishe will or desier the Deathe or Deprivacon of our Soveraigne Ladye the Queenes $\mathrm{Ma}^{\text {te }}$ (that nowe ys,) or any Thing directlye to the same Effecte. ${ }^{181}$

The ongoing investigation of Howard and his peers for just such activity at the time that this parliament was in session would have proved the relevancy of this passage to the Members of Parliament.

Despite the "Acte against sedicious Wordes and Rumors" and the denigration of prophecies in print, there was no let-up in the circulation of seditious prophecies during the 1580s. One such prophecy, which combined various strands from the British prophetic tradition to predict the restoration of Catholicism, appeared in Tolleshunt D’Arcy, Essex in April 1583:

Seke a crosse of stone between Gloster and the forest but they shall not find it, then shall they gooe to London and there shall the lyon doe greate harme and distruction, and then he shall gooe into Norfolke and there shalbe slayne of an elyphant. And then the poore commynaltie shall take the white horse for theire captaine and rejoice bycause there shall comm into England one that was dead and with him shall come the Ryall E. and th dead man shall sett the crownes of England on his hedd. And then the laws shall turne and then the people shall rejoice the deades mans commyne because sorowe and care shalbe almost paste. And then shall the ryall E., which is the best bloud borne in all the world, shall roote out all heresies cleane out of this realme restoring the churche and the Catholicke Faythe. A lyon, a horse, a liberd shall crowne E. by the help of the grete Egle.

John Tusser, probably the son of the Catholic gentleman and former parliamentarian Clement Tusser, an acquaintance of Sir Edward Waldegrave, was arraigned at Witham Assizes in July for distributing this prophecy, but was found not guilty. ${ }^{182}$

\footnotetext{
18123 Eliz., c. 2 .

182 J. S. Cockburn (ed.), Calendar of Assize Records, Essex Indictments Elizabeth I (London: Her Majesty's Stationery Office, 1978) p.241; TNA DL 26/38; J. J. Goring, 'TUSSER (TYSSARD), Clement (by 1520-61 or later), of Rivenhall, Essex'; The History of Parliament: the House of Commons 1509-1558; http://www.historyofparliamentonline.org/volume/1509-1558/member/tusser-(tyssard)-clement-1520-61-orlater; accessed 12 October 2012.
} 
Another Catholic prophecy was shared by Simon Yomans, a labourer of Little Dean, Gloucestershire, in August 1586. When discussing "the dearthe of corne and victuall" with Sybill Horte and her servant John Toye, Yomans told them that "it wilbe worse before it be better," for "the prophesie dothe speake" that there would be three battles within twelve months and that "our queen shalbe slayne." After that, however, "we shall have the latten lawes" and be ruled by "fower peeres and soe from thenceforthe a myrrye world." 183 Significantly, Yomans' prophecy envisaged an overthrow of the monarchical system, not simply a change of monarch. A similar prophecy, that "there should no King raigne in Englande," and that the realm would be "ruled by foure gouernours, to be elected and appoynted by the commons" had inspired the participants in Kett's Rebellion in 1549. ${ }^{184}$ As with Yomans' turn to prophecy, the rebellion was the result of a crisis in the agricultural sector, demonstrating how food shortages could fuel unrest and prophetic activity.

Protestants too prophesied Elizabeth's death. On 21 October John White, a 25 year old shoemaker in Rayleigh, Essex, declared at the shop of John Warley that "our queen shall lyve but a little whyle" and "she wilbe gone ere somer come." When he was interrogated concerning this by Arthur Herrys, White confessed to having "prayed that god would take away, for the synnes of the people, our goode prince, that the people for there synnes might be punished with some tyrant." According to one witness, he had also delivered speeches promoting sexual freedom and compared himself to John the Baptist. Herrys, reporting the incident to Lord Chancellor Bromley, commented that he thought White to be "overstudyed with Annabaptystycall conceyts." 185 Another case is that of Ralph Durden, a minister in Essex who declared himself Elijah and distributed "certaine papers... interpreting the Revelation of St. John after his owne fansye, and both in word and writing... uttered sume dangerous matter towching the estate of this Realme." A tailor of Cambridge who had become acquainted with Durden in prison, Robert Williamson, testified that on 23 February 1587 Durden had said that "come twelmonth England shall have a new prince, and that prince shall reigne but five monethes, and he shalbe a papist." He had further stated that any who did not go with him to build Jerusalem would be damned, and that he "should be kyng of the whole earth.",186

\footnotetext{
183 TNA SP 12/192 f.80r.

${ }^{184}$ Raphael Holinshed, The firste volume of the chronicles of England, Scotlande, and Irelande (London, 1577) p.1676.

185 TNA SP $12 / 194$ ff.87r-89r.

${ }^{186}$ BL MS Lansdowne 54 f.19r.
} 
By the mid-1580s prophecies that Mary's son James would rule over a united Britain were common in London and probably elsewhere. On 11 July 1584 John Carre, a yeoman of Southwark, London pronounced "that he hath harde say sundry tymes that the Scottishe wyf shall have a sonne that shall wynne all brittayne. And that he hath harde a songe that the scottishe kynge shalbe our governor."187 Such prophecies gained traction particularly among those dissatisfied with Elizabeth's rule. A number of people testified that, when questioned as to "what would move him to utter anye suche speeches," Carre responded that "the realm was spoiled for want of a good governor." 188

Prophetic interpretations of Mary's own significance continued to appear until her execution in 1587. On 11 August 1586 she was arrested for allegedly sanctioning an assassination attempt against Elizabeth in what became known as the Babington Plot. In September she was moved to Fotheringay Castle to be put on trial, passing through Leicester. ${ }^{189}$ Residents of the city discussed these events and their wider political implications within the framework of Merlinic prophecy. The Records of the Borough of Leicester record the examination in October 1586 of Charles Dubignon, who reported that he had heard an embroider named Edward Sawford say that "if the Queen of Scots were put to death there would be great trouble in England; that Merlin had prophesies [of] a pleasant goldern world after such troubles, and that the commons would rise if the poor were not relieved."190 Sawford claimed that he had been told of Merlin's prophecies by an elderly Catholic man, William Byard. The prophecies foretold that at the next parliament there would be great discord and Queen Elizabeth would be forced to flee into Wales for her safety, after which England would be invaded and "the crown would be lost and won once or twice" with three battles being fought at Westchester, Coventry and London. "Afterwards, in the greatest troubles, a dead man should come... and he should restore to every man his own wife and land, and set up four rulers in the land, and then he should go forth and conquer." 191 The prophecy contained many of the same elements as that which Simon Yomans had shared in Gloucestershire that same year, so evidently these predictions were widespread.

\footnotetext{
${ }^{187}$ J. S. Cockburn (ed.), Calendar of Assize Records, Surrey Indictments: Elizabeth I (London: Her Majesty's Stationary Office, 1980) p.262.

188 TNA SP $12 / 172$ f.10r.

${ }^{189}$ James Thompson, The History of Leicester: From the Time of the Romans to the End of the Seventeenth Century (Leicester: J. S. Crossley, 1849) p.278.

${ }^{190}$ Mary Bateson (ed.), Records of the Borough of Leicester, Vol. 3 (Cambridge: Cambridge University Press, 1905) p.229.

${ }^{191}$ Thompson, The History of Leicester, p.279.
} 
Sawford said that he did not know whether the dead man mentioned in the prophecy would be "King Edward the syxt or King Arthur."192 Prophecies and rumours of Edward VI's return had emerged during the reign of Mary I and continued to be circulated late into Elizabeth's. ${ }^{193}$ In A Discovrsive Probleme John Harvey complained of the "fond and vaine expectation" which "hath a long time rested in the minds not of one or two, or a few, but of great multitudes of the simpler sort in England about King Edward the Sixt, as though they were sure either of his arising from death, or his returne from I know not what Jerusalem, or other strange land." He also wrote that "counterfet suborned marchants of base parentage, haue sithence ranged abrode in the countrie, presuming to terme themselues by the roiall name of king Edward."194 One such impersonator was Robert Blosse, alias Mantell, a yeoman of London. Mantell was indicted at Essex in July 1578 for claiming that he was King Edward VI, but escaped from Colchester gaol the next year with the assistance of "sondery persones" including a London woman, Elizabeth Vessie, and "the wydowe Symonds."195 Upon his recapture the Privy Council informed the Justices of Assizes in Essex that it was "her Majesties pleasure" that Mantell should be executed as a traitor, both for his crimes and because "the long reserving of him hath geven occacion unto others to cast abroade seditious libels to the disturbance of her Highnes' estate." 196

It is likely that the prophecies that were current promising the return of Edward VI lent credence to Mantell's claim and helped him to gain support. Elizabeth Vessie was convinced because of a fortune she had been given by a Lancashire woman, Jane Standlie, around 1571. Standlie had told her that she "should be in great favour \& doo much for the kinge of this land," and that this would bring her into "great trobell... $\mathrm{w}^{\text {th }}$ the queen and $y^{\mathrm{e}}$ whole counsel." When Vessie met Mantell six years later she recalled what Standlie had told her and, thinking him to be the man spoken of in the prophecy, recounted it to him, then "tooke up his hand and blessed him \& confirmed $\mathrm{y}^{\mathrm{t}}$ all that $\mathrm{M}^{\mathrm{rs}}$ Janne had said \& told hir was trewe." 197

The rumours of Edward VI's return and the recurring theme of a dead man rising to rule England reflect in part a desire for male rule. Such sentiments were accentuated from the 1580s onwards as Elizabeth was then too old to marry and bear children. On 31

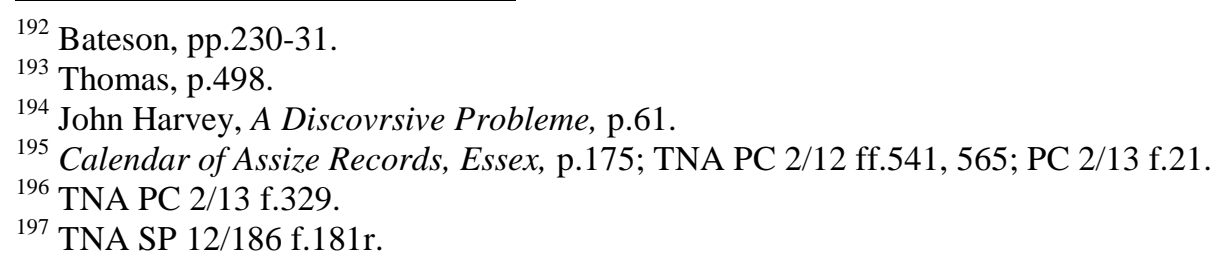


January, 1586 Joan Lyster of Cobham, Surrey publicly stated that "bycause [Elizabeth I] is but a woman she owght not to be governor of a Realme... and that the world wold change erre yt were longe."198

\section{Philip II and the Spanish Armada}

Philip II of Spain had begun planning an invasion of England after English forces landed in Galicia in October 1585. His intent was given added justification following Mary Queen of Scots' execution on 8 February 1587, at which point he effectively took up her claim to the English throne. In May 1588, with the support of the Papacy, he launched the Spanish Armada to conquer England and install a Catholic governor. ${ }^{199}$

As we have seen, prophecies that Philip would renew his reign in England had been present since Elizabeth's accession, and these continued to circulate throughout the 1570s and 1580s. In January 1577, for example, Antonio de Guaras, a Spanish merchant living in London, wrote that a 300 year old prophecy was being interpreted there which said:

Talpa ore Dei maledicta fratis sui gladio perebit [the mole, cursed by the mouth of God, shall die by the sword of their brother], which some people think applies to this Queen, as she, like a mole, is burrowing in the lands of her neighbours and is accursed by the mouth of God, since she is excommunicated by His vicar, and must surely die by the sword of his Majesty [Philip II], as she has so richly deserved. ${ }^{200}$

The prophecy being discussed was the "Prophecy of the Six Kings to Follow King John," which originated in the early fourteenth century and stated that "the Mole's reign will see the defeat and dispossession of this line of kings."201 Another prophecy that favoured the Spanish was discovered by the governor of Carlisle, Henry Lord Scrope, when he investigated a number of Scottish Catholics on behalf of Secretary Walsingham in 1584. He found writings in the chambers of one of these men that contained "fantastical and foolish prophecies" declaring that in 1563 "out of Philip's blood a worthy brood shall rise, who shall redeem the world's misdeeds with warlike enterprise," and prognosticating the time when "the mass shall last for ever and aye."202

\footnotetext{
${ }^{198}$ Calendar of Assize Records, Surrey, p.282.

${ }^{199}$ Geoffrey Parker, The Grand Strategy of Philip II (New Haven: Yale University Press, 1998) ch.6.

${ }^{200}$ Antonio de Guaras to (Zayas?), CSP Spanish, Vol. 15, p.538.

${ }^{201}$ T. M. Smallwood, 'The Prophecy of the Six Kings', Speculum, Vol.60, no.3, July 1985, pp.572, 575.

${ }^{202}$ TNA SP 15/28/1 ff. 126r-v, 134r, 138r.
} 
Expectations that Philip would win the crown of England were heightened when the Spanish Armada set sail from Lisbon on 28 May 1588, the year prophesied by Regiomontanus to herald, at the least, alterations of kingdoms. Many expected that the Armada would fulfil this prophecy. According to an anonymous letter sent from England, a copy of which was forwarded by its recipient to the Vatican, a marble slab had been uncovered at Glastonbury abbey upon which the words of the 1588 prophecy were carved. This was taken to mean that not Regiomontanus but Merlin was the true author, "and his dark science, or God's inscrutable providence, had brought them to light in these latter days just in time to warn Britons of the[ir] impending destruction."203 Bernardino de Mendoza, then ambassador to Henry III in France, was informed by a confidant in England that the Spanish Armada was taken to fulfil an "old prophecy about the soldiers who are to dominate England, coming with snow on the crests of their helmets." 204 Further, a sermon preached by Richard Bancroft at Paul's Cross reveals that word had reached England that the "holie maide of Lisbone" Sor María had prophesied the Armada's victory. ${ }^{205}$

Not all prophecy circulating at this time favoured Philip's cause, however. Bancroft also mentioned possessing a manuscript prophecy that proclaimed Elizabeth to be the Last World Empress, "ordained of God to be Queene of Ierusalem."206 This was the prophecy "of the Sibilles, Methodius and others" that Edward Topsell claimed "the learneder sort" in England were "much affected with," that the Last World Emperor would establish their throne in Jerusalem and usher in a global period of peace in which the one true religion was preached before the final days. ${ }^{207}$

Another positive prophecy for Protestant England was produced by the German Paul Grebner. On 16 July 1587 Grebner wrote to Francis Walsingham requesting that he might present a volume of his prophecies to the Queen with the hope that they would be published in England at her expense. ${ }^{208}$ Grebner's request seems to have been ignored at

\footnotetext{
${ }^{203}$ Garrett Mattingly, The Armada (New York: Houghton Mifflin Company, 2005) p.178.

${ }^{204}$ Bernardino de Mendoza to the King, CSP Spanish, Vol. 17, p.214.

${ }^{205}$ Richard Bancroft, A Sermon Preached at Paules Cosse the 9 of Februarie, being the first Sunday in the Parlieament, Anno 1588 (London, 1588) pp.6-7; Richard L. Kagan, 'Politics, Prophecy, and the Inquisition in Late Sixteenth-Century Spain', in Mary Elizabeth Perry and Anne J. Cruz (eds.), Cultural Encounters: The Impact of the Inquisition in Spain and the New World (Berkeley: University of California Press, 1991) p.119.

${ }^{206}$ Bancroft, p.8.

${ }^{207}$ Edward Topsell, Times Lamentation (London, 1599) p.63; Glyn Parry, 'Mythologies of Empire and the Earliest English Diasporas', in T. Bueltmann, D. T. Gleeson and D. M. MacRaild (eds.), Locating the English Diaspora 1500-2010 (Liverpool: Liverpool University Press, 2012) p.22.

208 TNA SP 82/2 ff.166r-167r.
} 
first, for in November of that year one of the Privy Council's contacts in Hamburg, Dr. John Schulte, wrote to Walsingham on his behalf. Schulte wrote that Grebner's prophecies contained "many things... which concern her and her realm, and which might console and encourage her in the present tumults and evils threatening on all sides, as they are of happy omen for her and all other Evangelical princes." ${ }^{209}$ He described Grebner as a "good and educated German... a zealous student of theology and the scripture," but also "a simple man, formerly a schoolmaster, not very learned in history, and with even less knowledge of the condition (or even the names) of the regions and realms of the world," a description which strengthened Grebner's prophetic authority by suggesting that the knowledge displayed in his prophecies could only have come from divine inspiration.

The response to Grebner's prophecies proves that Protestant leaders were not inherently hostile to prophecy during Elizabeth's reign. Walsingham agreed to assist Grebner in exchange for intelligence services, and the prophecies were printed in England by John Wolfe in 1590. ${ }^{210}$ The clergyman William Covell referred to them in his 1595 Polimanteia as an example of true prophecy sent from God. "The trueth of such like inspirations," he asserts, "are knowne by their endes; as the Prophet Jeremie testifieth," and many of the things which Grebner had foretold, such as the succession of the King of Navarre to the crown of France in 1589, had indeed come to pass. ${ }^{211}$ The prophecies attained even greater popularity in the seventeenth century, appearing several times in print and interpreted as predicting the execution of Charles I and the restoration of his son. $^{212}$ These later editions claimed that Grebner had presented his prophecies to the Queen in 1582, and that they were afterwards deposited by Thomas Neville in the library at Trinity College in Cambridge, a claim that some modern historians have repeated. ${ }^{213}$ This is, however, incorrect; apart from the letters to Walsingham, the manuscript itself is dated 29 September $1585 .^{214}$

\footnotetext{
${ }^{209}$ TNA SP 82/2 ff.208r-209r.

${ }^{210}$ TNA SP 82/3 ff.91r-v; Edward Arber (ed.), A Transcript of the Registers of the Company of Stationers of London, Vol. 2 (London, 1875) p.548.

${ }^{211}$ Covell, Polimanteia, sigs.O1r-O2r.

212 Thomas, p.468.

${ }^{213}$ George Withers, Vaticiniu votivum or, Palaemon's prophetick prayer... To which is annexed a paraphrase on Paulus Grebnerus's prophecie (London, 1649) p.25; Capp, p.279; Taylor, p.101.

${ }^{214}$ Montague Rhodes James, The Western Manuscripts in the Library of Trinity College, Cambridge, Vol. 2 (Cambridge: Cambridge University Press, 1901) pp.388-9.
} 
Another event which Grebner's prophecies were retrospectively applied to was the defeat of the Spanish Armada in August 1588. ${ }^{215}$ The English victory contradicted the Catholic interpretation of prophecies and was celebrated in England as proof that God's providence favoured Protestantism. The second edition of Maurice Kyffin's Blessednes of Brytaine, published in late 1588, ridiculed those who had "Cast Constellations; And yet [were] deceyv'd by deepe Diuinations:"

The fatall yeere of fearefull Eighty Eight,

Forethreatning falls of Empires, Realms, \& Kings...

Is Now nigh spent, and yet our Realm \& Queene,

Through Gods great Pow'r, secure in Saftie seene. ${ }^{216}$

Because the prophecy attributed to Regiomontanus had not specified what alterations of kingdoms would occur if the End did not come belief in its validity endured. According to Francis Bacon, the "sending of that great fleet" was thought by many to have fulfilled the prophecy that 1588 would be a "mirabilis annus," it being "the greatest in strength... of all that ever swam upon the sea." 217 One who expressed this belief was William Fulke, the author of Antiprognostication, who wrote in a dedication to Queen Elizabeth that "whereas the adversaries made no small account of that Astrologicall prediction... we may now safely declare [its] accomplishment" by adding a line professing the Papists' defeat: "clade papistarum, Faustus ubiq; piis." 218 While unfulfilled the 1588 prophecy had offered hope to Catholics that their religion might be restored in England, in retrospect it was taken to prove the truth of the Protestant cause. This affirms the distinction made by Paul Strohm between prospective and retrospective uses of prophecy, the former best serving the powerless seeking political change, and the latter those already in power and seeking its consolidation. ${ }^{219}$

In A discoursiue probleme concerning prophesies John Harvey praised the government's enactment of the 1563 statute against "imposturall prophets," commenting that "their devises [have] been found in trial not onely very dangerous, and perillous practises, but

\footnotetext{
215 James Maxwell, Admirable and Notable Prophecies (London, 1615) p.87.

${ }^{216}$ Maurice Kyffin, The blessedness of Brytaine... Newly set foorth (London, 1588) sig.C3v.

${ }^{217}$ Francis Bacon, The Works of Francis Bacon, Vol. 2 (London, 1819) pp.342-3.

${ }^{218}$ William Fulke, The text of the New Testament of Iesus Christ (London 1633) dedicatory epistle.

${ }^{219}$ Paul Strohm, England's Empty Throne: Usurpation and the Language of Legitimation, 1399-1422 (New Haven: Yale University Press, 1998) pp.6-7.
} 
also very pernitious, and intolerable criminall villanies. ${ }^{220}$ In the 1570 s and 1580 s a persistent flow of prophecies offered alternative visions of the future to the aims of England's political and religious leaders, who attempted to stem this prophetic tide through legal action and printed propaganda. Yet the possibility of prophecy was rarely denied altogether. Harvey closed his tract with an epilogue in which he stated that it was not his intent to "confute, or [in] any way disallow any laudable practice, or profitable exercise of any lawfull and warrantable Art, learnedly and honestly proceeding to a provident fore-sight, or fore-knowledge of the future."221 Prophecies could be employed in the government's favour, as demonstrated by the use of Grebner's and Regiomontanus's prophecies. It was only prophecies that "ingender[ed] troublesome sturs, tumults, uprores, seditions, mutinies... the very prophesies of the deuill" that came under attack. 222

\footnotetext{
${ }^{220}$ John Harvey, A discoursiue probleme, p.71-2.

${ }^{221}$ Ibid., pp.76-7.

${ }^{222}$ Ibid., p.71.
} 


\section{CHAPTER THREE (1588-1603)}

Despite England's victory over the Spanish Armada in 1588, the Anglo-Spanish War continued for the remainder of Elizabeth's reign. The government increasingly enforced religious conformity, targeting both Catholics and, from 1589, Puritans who promoted further reform of the Church of England. Elizabeth's government also struggled with war in Ireland, failed harvests, and economic crises during the 1590s, which fostered discontent amongst the population. While the succession remained unresolved, the Privy Council favoured James VI of Scotland, as did Elizabeth, unofficially. This chapter will look at the use of appeals to divine authority in the religious politics of the latter part of Elizabeth's reign, the role of prophecy in rebellion, prophecies of Elizabeth's death, and the application of prophecy to the Union of the Crowns upon James's succession in 1603.

\section{Religious Politics and Divine Prophecy}

Through its claims to divine authority, prophecy offered the underprivileged in England an authoritative voice they otherwise lacked. Some of Elizabeth's subjects therefore compensated for their lack of political power by claiming that God had endowed them with prophetic knowledge. Such claims usually expressed dissatisfaction with the religious establishment, and while they were made throughout Elizabeth's reign, the government's stricter enforcement of conformity in the later period increased their frequency in the records and their political significance.

Many self-proclaimed prophets attempted to address Elizabeth directly. For example, when Elizabeth inspected her troops at Tilbury in August 1588, a glover named Robert Dickons delivered a vision to her which he claimed to have received from the "Angel of the Lord" as a young man. In this vision he had seen "a feilde $\mathrm{w}^{\text {th }}$ many flocks of sheepe." Among them arose a lion " $w^{\text {th }}$ many wolfes and foxes folowinge him." The lion killed many of the sheep before a sheep with wool as rough as teeth and a tongue like a two-edged sword stopped it in a final pasture. A man in the midst of the pasture, seeing this, came and struck down the lion, forcing the wolves and foxes to flee. When they were all slain or gone the man "stoode and cryed wth a loude voice" that there was "but one sheperd" for that pasture, and "one flock.",223

${ }^{223}$ BL MS Lansdowne 99 ff.18r-v. 
Dickons explained his vision: the pasture represented England, the lion the Pope, and the wolves and foxes the civil magistrates and "false teachers" who follow him. The sheep signified those who "fled... from the traditions of the pope and are come to the true faithe in Christe," and the one with the rough wool "the prince of England," Elizabeth. The man was "the angell of God sent to defende his anointed from the Lyones rage and to destroye him $\mathrm{w}^{\text {th }}$ all other traytoures and rebelles that pretend any treason againste her $\mathrm{ma}^{\text {tie }}$," and his voice that of "the preachers $\mathrm{w}^{\text {ch }}$ testifie that there is but one true confession $\mathrm{w}^{\mathrm{ch}}$ nowe is set fourth in England," and that "it is beste for all true Christianes to gather into that true confession." In February 1589 Dickons wrote to the Queen requesting an audience, warning her that if her clergy did not preach repentance the Lord would smite the earth with plagues, famine, sword and pestilence. He was uncertain whether she had received his vision, as "by the meanes of my poor estate I am kepte frome youre Royale maiestie nether can I be suffered to speake to any of your privy consale."224

Dickons' request was denied, the annotation on his letter describing him as "a distracted glover."225 The Council may have been aware that in 1582 Dickons had claimed the role of Elijah, but confessed before the preacher Henry Smith to having invented his visions, and thus viewed him as a fraud. ${ }^{226}$ The government similarly dismissed a number of other supposed prophets who attempted to gain Elizabeth's attention as mad. Writing to the Earl of Essex in 1594 the French ambassador Beauvoir la Nocle mentioned a "fool" who considered himself "a greater prophet than Moses" and had attempted to gain an audience with the Queen "to reveal matters touching her service and person.,"227 In 1601 John Richardson, described as "a frantiyck man," petitioned the Queen for her "to heare a message or errand from God Almightie, sente by the revelation of the holie ghoste." 228

The government took another false prophet, William Hacket, far more seriously. An illiterate serving man from Northamptonshire, Hacket became a convinced Presbyterian in the 1580 s and, believing he held a unique prophetic vocation, preached throughout England that God had sent him to prepare for the second coming of Christ. When in London in 1591 he met two Puritan gentlemen, Henry Arthington and Edmund Copinger, whom he convinced of his calling. Arthington and Copinger also believed that

\footnotetext{
${ }^{224}$ Ibid.

${ }^{225}$ BL MS Lansdowne 99 f.18r.

${ }^{226}$ Henry Smith, The Sermons of Mr. Henry Smith, Thomas Fuller (ed.), Vol. 2 (London: William Tegg, 1866) pp.279-81.

${ }^{227} \mathrm{CP} 172 / 118$.

${ }^{228} \mathrm{CP} 86 / 83$.
} 
they had an "extraordinary calling" from God, and together the three men aspired to overthrow the bishops and institute Presbyterianism by inspiring a popular uprising. ${ }^{29}$ As Michael Winship has pointed out, the conspiracy was motivated by the lack of any viable political options for the Presbyterian movement by this time. Elizabeth had opposed any parliamentary efforts to reform the Church of England during the 1580s, driving the movement underground, and the Martin Marprelate publication campaign ridiculing the bishops in 1588 and 1589 had embarrassed the movement and provoked fierce reaction from the government, leading to the imprisonment of nine leading Presbyterian ministers in $1590 .^{230}$

On the morning of 16 July 1591 Arthington and Copinger mounted a cart in Cheapside, claiming to be God's prophets of mercy and judgment and declaring Hacket to be Jesus Christ and King of Europe. They promised "great comfort, and vnspeakeable ioyes to all that should repent" and "terrible Iudgements, if they repented not... especially vpon that Citie of London."231 News of this "being quickly blowen through the citie... [and] brought to her Maiesties eares," two Privy Councillors were despatched to investigate the matter and arrested the three men. ${ }^{232}$

The incident provoked a violent reaction from the government because the men had explicitly and publicly challenged the Queen's sovereign authority. Thomas Phelippes informed William Sterrell that "though they be but in the rank of mad men, it is thought the State must be satisfied, especially on the prophet of vengeance [Arthington], because he has said the Queen is not to reign any longer, for rejecting the petitions of the faithful" to save the Presbyterian leaders then on trial in the Star Chamber "and neglecting the cause of God and his Church." Furthermore, Arthington and Copinger's speech in Cheapside had identified Archbishop John Whitgift and Sir Christopher Hatton, both members of the Privy Council and Presbyterianism's principal opponents, as "traitors to God and the realm.",233 Hacket was ordered to be "most strictlie and severlie examined" and if necessary "compelled by torture to utter and discover the bottom of his wicked and divelish purpose," as the Privy Council sought to implicate the Presbyterian

\footnotetext{
${ }^{229}$ Alexandra Walsham, 'Hacket, William (d. 1591)', ODNB; http://www.oxforddnb.com/view/article/11840; accessed 8 March 2013.

${ }^{230}$ Michael P. Winship, 'Puritans, Politics, and Lunacy: The Copinger-Hacket Conspiracy as the Apotheosis of Elizabethan Presbyterianism', The Sixteenth Century Journal, Vol. 38, no.2, Summer 2007, pp.347-50.

${ }^{231}$ Richard Cosin, Conspiracie for Pretended Reformation (London, 1592) pp.55-7.

${ }^{232}$ Cosin, Conspiracie, pp.59-60; TNA PC 2/18 f.410.

${ }^{233}$ TNA SP $12 / 239$ ff. $123 \mathrm{v}-1124 \mathrm{r}$.
} 
ministers in the conspiracy. ${ }^{234} \mathrm{He}$ was convicted of treason and publicly executed in London on 28 July 1591. Copinger starved himself to death in prison, while Arthington was freed in 1592 after recanting his errors in The seduction of Arthington by Hacket, which recounted how he had been bewitched by Hacket. ${ }^{235}$

Whitgift and his allies presented the incident in Cheapside as further evidence of the political threat of Presbyterianism. In September 1591 Richard Cosin, Whitgift's protégé, wrote A Conspiracie for Pretended Reformation which claimed that Hacket, Copinger, and Arthington, the "seduced instruments" of Satan, had been complicit with the Presbyterian ministers, whom they had consulted while organising their abortive insurrection. $^{236}$ In 1593, to support Whitgift's parliamentary campaign against the Presbyterians, his chaplain Richard Bancroft re-emphasised this connection in Dangerous positions and proceedings, helping the "Act to retain the Queen's subjects in their Obedience" criminalising Protestant non-conformity to pass through parliament. ${ }^{237}$

Having the least political power of all, women also claimed to have received visions from God in favour of "true religion." As the "weaker vessel," women were considered to be more receptive to outside influences, whether divine, earthly, or demonic. In February 1580, a "yong mayden" of Flint, Elizabeth Orton, claimed that she had received visions which were "put into writing \& scattered abroad amongst the papists \& ignorant people" of Chester, where popery was still strong. When the authorities became involved Orton was forced to confess that the visions were invented, saying that she had been "seduced by a vile runnagate Papist," the schoolmaster Hughes. ${ }^{238}$ In July 1593 another woman was imprisoned in Winchester for claiming that she had slept for fifteen days and nights, during which time she had seen Mary Tudor of England and Mary Queen of Scots in heaven, and "King Henry with the Earl of Lecester and many others in hell." Most traitorously, she had prophesied "that Queen Elizabeth shall dye before

\footnotetext{
${ }^{234}$ TNA PC 2/18 f.416.

${ }^{235}$ Cosin, Conspiracie, pp.71-3; Henry Arthington, The seduction of Arthington by Hacket especiallie, with some tokens of his vnfained repentance and Submission (London, 1592).

${ }^{236}$ Cosin, Conspiracie, sig.B2v.

${ }^{237}$ Richard Bancroft, Davngerovs positions and proceedings, published and practised within this Iland of Brytaine (London, 1593); 35 Eliz., c.1.

${ }^{238}$ The lords \& others of the council to William Chaderton', 22 June 1581, in Francis Peck (ed.), Desiderata Curiosa (London, 1779), no.XXXIII, p.105; Barnabe Riche, The true report of a late practise enterprised by a Papist (London, 1582).
} 
Mychaelmas." 239 Loyal Protestants considered the promotion of such ideas to be Satan's work, and this woman was rumoured to be a witch. ${ }^{240}$

\section{Prophecy and Rebellion}

As throughout Elizabeth's reign, prophecies continued to inspire potential rebels against the established order. The Privy Council was perpetually on the alert for even small-scale local disturbances that could spiral out of control into larger rebellions. When participants in a protest against enclosure in Broughton, Buckinghamshire in August 1593 were alleged to have "combined and associated" with "one John Harries, a supposed prophesier, tending to further disorder and tumult," the Council ordered his examination and imprisonment if he was found "to hath lewdlie prophesied, as is suggested."241

The government maintained strict controls over the printing of prophecies because of their potential to encourage rebellion and disorder. When Richard Watkins' and James Roberts' monopoly on printing almanacs and prognostications, initially created in 1578 , was renewed in December 1589 it was commented that "manye fantasticall and fond prophecienges" which had "bene accustomed to be sett forthe in Almanackes and Prognostycacyons in former tymes" were "nowe lefte unprinted," despite "dyvers suche... yearelye com[ing] to theyr handes." 242 Those who printed unauthorised prognostications faced destruction of their equipment and six months imprisonment and were forbidden from returning to the trade. ${ }^{243}$ In 1595 the Company of Stationers seized and destroyed the press of Abell Jeffes after he "disorderlie without Aucthoritie and contrarie to the Decrees of the starre chamber" printed the "lewde booke" A Most Strange and Wonderfull Prophesie. ${ }^{244}$

Jeffes' pamphlet contained two apocalyptic prophecies. The first, attributed to a “famous and excellent Doctor in Astrologie, Master Iohn Cypriano," predicted events in the North, West, South, and East through animal symbolism. Out of the East, for example, would "come a dismall blacke Dogge," representing “the Turke," which would

\footnotetext{
239 'Newsletter to Fr. Persons from London', 20 July 1593, printed in Anthony G. Petti (ed.), The Letters and Despatches of Richard Verstegan (London: Catholic Record Society, 1959) p.180.

${ }^{240}$ Petti (ed.) p.177.

${ }^{241}$ TNA PC $2 / 20$ f. 550.

${ }^{242}$ Arber, Vol. 2, 817-8; Cyndia Susan Clegg, Press Censorship in Elizabethan England (Cambridge: Cambridge University Press, 2004) p.12.

${ }^{243}$ Jennifer Forster, 'Anticipating the Apocalypse: An Elizabethan Prophecy', The Historian, Vol. 63, no.3, Spring 2001, pp.600-17.

${ }^{244}$ Arber, Vol. 2, p.825. The Star Chamber decree of 1586 required that all books be approved by the Archbishop of Canterbury or Bishop of London prior to publication (Forster, p.602).
} 
invade Germany and there lose one of his limbs, after which he would "forsake his maister," Mahomet, "and choose him a new name," that of Christian, "wherby the Scripture shall be fulfilled," signifying that "the day of doombe is at hand." The second, attributed to Tarquatus Vandermers, offered predictions for each month of 1569. Bernard Capp has suggested that the authorities were provoked by the prediction for March, that an island would be flooded for the sins of its ruler. ${ }^{245}$ Wars, plague, famine and drought were also prognosticated until in November "a triumphant conquest shall be bruted through the world," and in December "all things [would be] united up in peace" and "religion preached truly through the world," recalling the Last World Emperor prophecy. $^{246}$

The 1590s saw an outbreak of rebellion among Catholics in Ireland, and English observers often claimed that these rebels were inspired by prophecy. One prophecy reported by the Lord Deputy of Ireland, Sir William Fitzwilliam, in 1593 promised that "when two Hughes lawfully lineally and immediately succeede each other as O'Donnells" the second would "be a monarch in Ireland" and banish "all forrein nations and conquerors." This prophecy had "allure[d] the countrey people... to flatter follow and wholy to favour" the younger O'Donnell, bolstering his campaign against the English which he began that year. ${ }^{247}$ Another Irish prophecy recorded as far away as Wales in January 1599 asserted that O'Donnel's ally Hugh O'Neill, the Earl of Tyrone, "should prevail against the English nation."248 Prophecies also could instil fear and uncertainty amongst rebels, however. In January 1596 the new Lord Deputy, William Russell, commented that Irish rebels feared Scotland "in respect of a foolish prophecie they have, that none but the Scott shall prevayle against them," and in November 1601 Sir George Cary reported that the rebels were troubled by "a foolish prophecy amongst them" made by a Scotsman. ${ }^{249}$ The next month Tyrone admitted to some of his followers that "he was troubled with a prophecy that he should lose his life in this action of Munster."250

In England, too, people expected prophecy to reveal how the Irish rebellion would be resolved. The London physician and astrologer Simon Forman, though he usually

\footnotetext{
${ }^{245}$ Capp, p.70.

${ }^{246}$ John Cipriano and Tarquatus Vandermers, A most strange and vvonderfull prophesie vpon this troublesome world, trans. Anthony Hollaway (London, 1595).

${ }^{247}$ TNA SP 63/170 f.31v; John J. Silke, 'O'Donnell, Hugh, lord of Tyrconnell (1572-1602)', ODNB; http://www.oxforddnb.com/view/article/20554; accessed 6 March 2013.

248 TNA SP 63/203 f.38r.

${ }^{249}$ TNA SP 63/186 f.89v; SP 63/209/2 f.191v.

${ }^{250}$ TNA SP 63/209/2 f.257r.
} 
avoided political matters, interested himself in the career of the Earl of Essex, Robert Devereux, Lord Lieutenant of Ireland from 1599. On March 14, 1599, Forman set a horoscope to predict the fate of Essex's expedition to Ireland, the results of which were that the end of his voyage would bring "negligence treason hunger sicknes \& death." Upon his return "moch treachery shall be wrought againste him" and "he shalbe Imprisoned or haue great troble for he shall find many enimies in his return \& haue great losse of goodes \& honor." 251 Indeed, Essex's mission ended in failure and when he returned to London the following September in defiance of the Queen's order he was placed under house arrest and eventually removed from public office. ${ }^{252}$ Forman retained his interest in Irish affairs, and on September 19, 1600 he cast to know what would come of the Earl of Desmond, who was to be released from the Tower and sent back to Ireland in the hope that he could pacify the populace. ${ }^{253}$

Essex became the focus of greater prophetic interest when he led an attempted rebellion against the Queen. On 8 February, 1601 he marched into London with three hundred followers but, failing to gather support there, surrendered before the day was over. In the days following, Forman cast to know whether Essex and his co-conspirators would live or die. ${ }^{254}$ An astrologer called Woodhouse published an interpretation blaming the uprising on a lunar eclipse the previous year. He had calculated that the eclipse would cause "the unfortunate state of sundry great persons, ecclesiastical persons, lawyers, rulers, \&c" from 20 January 1601 until 12 July 1603, with the effects greatest between 18 November 1601 and 14 September 1602. Fearing that the prediction of even greater tumults might inspire further disorder, the government confiscated the book. ${ }^{255}$

Many of Elizabeth's loyal subjects shared similar fears, and informed the government of other dangerous prophecies in circulation. In March 1601 John Garnons delivered some writings to Sir Robert Cecil which he had received from John Notte, "a gentleman well affected in relygyon dwellyng in Crycadarne in the countye of Brecknockshire," Wales. ${ }^{256}$ These contained accounts of seditious speech related to the Earl of Essex's rebellion the previous month and mention of "divers credible reports"

\footnotetext{
${ }^{251}$ BL MS Ashmore 219 f.23r quoted in Barbara Howard Traister, The Notorious Astrological Physician of London: Works and Days of Simon Forman (Chicago: University of Chicago Press, 2001) p.179.

${ }^{252}$ Paul E. J. Hammer, 'Devereux, Robert, second earl of Essex (1565-1601)', ODNB; http://www.oxforddnb.com/view/article/7565; accessed 5 March 2013.

${ }^{253}$ BL MS Ashmore 236 f.215r, quoted in Traister, p.180.

${ }^{254}$ BL MS Ashmore 411 ff.22r, 25v, 30r, quoted in Traister, p.180.

${ }^{255}$ Vincent Hussey to _ 18 February 1601, Mary Anne Everett Green (ed.), Calendar of State Papers, Domestic Series, of the Reign of Elizabeth, 1598-1601 (London: Longman \& Co., 1867) pp.583-5.

${ }^{256} \mathrm{CP} 77 / 75$.
} 
which Notte had heard around 1596 "that one Sir Lewes Devett a pryst \& a soothsayer... wold often say that none of her $\mathrm{Ma}^{\text {ties }}$ enemies shold prevayle against her by any meanes" until after she had reigned forty-two years, i.e. from 17 November 1600, and that if she survived the five years following, then "she should reign long in her kyngdome." While assuring Garnons that he discounted such utterances, Notte worried that the Queen's enemies might "build their actions upon the speeches of the said pryst."257

The papers delivered to Cecil also contained descriptions of prophetic dreams in which Notte's wife (and Garnons' goddaughter) Joan had been warned of dangers to the Queen and to Cecil. The night before Essex's rebellion she had dreamt "very lyvely of her ma ${ }^{\text {tie }}$, and thought she sawe many arrows sett at her out of steele bowes: whereby she was in great dangr." 258 In another dream Anne Boleyn had appeared and told her that Elizabeth should not travel further than from Whitehall to St. James between Whitsontide and Michaelmas, "and in doinge she should lyve longer than ever any kinge or queene dyd in England to the utter overthrowe of her enemies, and comfort of her... subiects."259 She also dreamed that Cecil risked being poisoned. ${ }^{260}$ While Garnons described these as merely "fantastycall dreames," he still thought it worth passing them on to Cecil. ${ }^{261}$

\section{Catholic Persecution and Prophecies of Elizabeth's Death}

Elizabeth's advancing age, combined with increasing dissatisfaction with her rule, ensured that prophecies of her death became increasingly common towards the end of her reign. Many of these originated amongst the Catholic population, as they suffered even greater persecution in the wake of the Spanish Armada. The Armada's defeat had not left England's people feeling any more secure, and these prophecies often incorporated the prospect of foreign invasion.

The Privy Council strengthened its policies against Catholics in England partially because of predictions of another Spanish invasion. In November 1591 Burghley persuaded Elizabeth to publish a Proclamation establishing commissions in "every Shire, Citie, and Port" to identify Catholic recusants and requiring anyone with knowledge of missionary priests to report to the commissioners or else "be punished as abettours and mainteiners of traytours." The Proclamation justified these measures by emphasising

\footnotetext{
${ }^{257}$ CP 77/74.

${ }^{258} \mathrm{CP} 77 / 74$

${ }^{259}$ CP 77/72.

${ }^{260} \mathrm{CP} 77 / 74$.

${ }^{261}$ CP 77/75.
} 
how a Spanish invasion would be facilitated by the priests in England, which both Queen and Council feared because John Dee had "told the Counsel by his calculation, that the Realme indeed shalbe conquered" in the summer of $1592{ }^{262}$

Prophecies of Elizabeth's death helped to sustain Catholic hopes that their persecution would soon come to an end. In February 1592 one of Thomas Phelippes' informants using the name Henry Saintman reported that " $[t]$ he Catholickes have great prophecies that the Queen shall die this year." He thought these to be "devised by the priests, who intend some such thinge." 263 Yet lay Catholics also sought out such predictions themselves. In 1593 a gentlewoman, Jane Shelley, was imprisoned in the Fleet for "enquiring of a sorcerer how long Her Majesty should live."264 Shelley had approached an acquaintance, Alice Haydon, asking her to name a cunning man who could find her lost goods. ${ }^{265}$ Haydon introduced her to one Shepton who referred her to John Alfrey. The damning evidence came from Alfrey. He alleged that Shelley had asked him whether he thought the Queen would continue long, because she believed that there would be an alteration and great troubles shortly. If he could calculate for her the conjunctions of certain planets, she believed that she could determine the timing and nature of this alteration. Further, she had asked what would become of "the Catholiques aswell that are in prison as abrode" after Elizabeth's fall. She asked specifically about Philip Howard, Earl of Arundel and son of the late Duke of Norfolk, who had been a prisoner in the Tower since $1585 .^{266}$ Her own husband, William Shelley, was also a prisoner in the Fleet for "disobedience in matters of religion," and Jane confessed to having consulted the astrologer John Fletcher, a Cambridge Fellow, concerning whether or not he would escape execution. ${ }^{267}$

The imprisoned Catholics also hoped that a change of monarch might bring them their freedom. The Earl of Desmond, James Fitzgerald, a prisoner in the Tower since

\footnotetext{
${ }^{262}$ A declaration of great troubles pretended against the realme by a number of seminarie priests and Jesuits (London, 1591); Robert Parsons, A briefe apologie, or defence of the Catholike ecclesiastical hierarchie (Antwerp, 1601) sig.F3r-v.

${ }^{263}$ TNA SP $12 / 241 \mathrm{f} .81 \mathrm{r}$.

${ }^{264}$ CP 23/71.

${ }^{265}$ Locating lost or stolen property was one of the most common functions of the cunning man in Elizabethan England, along with healing, fortune telling, and other forms of popular magic. See Thomas, ch. 8.

266 TNA SP 12/244 ff.88r-90r; J. G. Elzinga, 'Howard, Philip [St Philip Howard], thirteenth earl of Arundel (1557-1595)', ODNB; http://www.oxforddnb.com/view/article/13929; accessed 4 March 2013.

${ }^{267}$ TNA SP 12/244 f.88r; PC 2/13 f.565; John Venn (ed.), Alumni Cantabridienses, pt 1, vol. 2 (Cambridge: Cambridge University Press, 1922) p.149.
} 
1584, had also sent a messenger to Alfrey. ${ }^{268}$ Stephen Trefulacke, a gentleman with whom Alfrey had spoken of the matter, deposed that the Earl had desired to know how long the Queen would live, though Alfrey denied this allegation, admitting only that Desmond had earnestly sought to speak with him "towchinge his libertie or towchinge the Queen.”269 Alfrey clearly enjoyed a reputation as a sympathetic cunning man amongst Catholics, but by informing against Jane Shelley he seemingly satisfied the authorities that he did not pose any danger.

Similar prophecies spread among Catholic prisoners throughout England. In 1595 Edward Hall, the porter at Wisbech Castle in Cambridgeshire, a prison for Jesuits and missionary priests, was investigated for speeches favouring popery. ${ }^{270}$ In March 1596 John Williams, a servant to Thomas Steward in the Isle of Ely, added to the accusations against Hall by claiming that when he stayed at the castle's porter's lodge in October 1595 two of the prisoners came in, one of whom, Edmond Caverley, announced that they were "but dead men, as they looked for nothing but death." To this Hall had replied "No, no, Mr. Caverley, 38 is at hand."271 This implied that the $38^{\text {th }}$ year of Elizabeth's reign would improve Catholic fortunes, probably by means of her death. Hall denied that he had spoken these words, countering that Williams was his "greatest enemy" and that his accusations reflected personal grievances. ${ }^{272}$

If one year failed to bring the prophesied religious changes, Catholics could always pin their hopes on the next. One Bardell, a tenant of Sir Edward Dymoke in Conesby, Lincolnshire, was investigated in 1598 for a book containing "foolish prophecies and vain" which predicted that the Pope would again "have tribute within this realm, after that her Majesty had reigned forty years."273 In 1602 a tailor from Broadmayne, Dorset, claimed that "the principal recusants" commonly overawed "the poorer sort" by persuading them "to hold patience until the good day cometh," which they promised would "not be long." 274

One surviving manuscript from the collection of Henry Stanford prophesied that in 1602 "a popes sonne wthout ever drawing sword shall make all or most part of

\footnotetext{
${ }^{268}$ Anthony M. McCormack, 'Fitzgerald, James fitz Gerald, fifteenth earl of Desmond (c.1570-1601)', ODNB; http://www.oxforddnb.com/view/article/9563, accessed 29 January 2013.

${ }^{269}$ TNA SP $12 / 244 \mathrm{ff} .88 \mathrm{v}-89 \mathrm{r}$. Trefulacke had been found to possess many books on astrology, conjuring and alchemy (SP 12/243 f.307r.)

${ }^{270}$ TNA SP $12 / 255$ f. $17 \mathrm{r}$.

271 TNA SP $12 / 256$ f.191r

272 TNA SP $12 / 256$ ff.233r-v.

${ }^{273} \mathrm{CP} 63 / 58$.

${ }^{274}$ CP 95/69.
} 
Christendom subiect vnto him" and would "come into England greatly welcomed of many." This prophecy obviously originated from a non-Catholic source, since it stated that this leader would prove to be a tyrant, and that after the "death of many Innocentes \& effusion of muche bloud vppon ye Earthe" he would be "overthrowen \& chased away."275 Stanford had access to élite texts through his position as a tutor in Sir George Carey's household, indicating that the prophecy may have been circulated within the Court. ${ }^{276}$

Prophecies that Elizabeth's death would result in disaster for England were reasonably common. At Shrovetide in 1595 Anne Dryland, a servant to the London silk weaver Richard Garret, prophesied that the Queen would die within three years and England would be overrun by its enemies. Garret informed the authorities, and in June the Lord Mayor, Sir John Spencer, committed Dryland to the Wood Street Counter Prison. Garret testified that she had used holes in the ashes she had raked up in the kitchen to foretell the birth of a child and the introduction of a new servant to the household, so she probably used a similar method to determine the Queen's fate. ${ }^{277}$

Other prophecies suggested that Elizabeth's death would precipitate civil war, not an unlikely outcome given her refusal to name a successor. On 3 June, 1595 John Fuller, a smith from Heathfield, Sussex, discussed a book containing "a prophesie of all the kings [who] had reigned a long tyme, and it had come to passe as it was conteyned in that booke; viz., when hempe is come and gone, happye were he out of England."278 This refers to a well-known prophecy using the initials of Henry VIII, Edward VI, Mary, Philip, and Elizabeth. Francis Bacon claimed he first heard it when a child, indicating that it had been circulating since at least the 1560s. His version reads "When Hempe is sponne/England's done," which he said was "generally conceived" to mean that "after the princes had reigned... England should come to utter confusion." 279 Fuller also stated that "the prophesie did shewe there should be a change (meaning the death of the queen) within seven years, and then the boxe should rise and get the victorie, but he should enjoye it a short tyme but should be putt downe by a poole." 280

George Barrett, a labourer of Dulwich, London, also expected that Elizabeth would die in 1602. On 27 November 1599 he told Thomas Rowse and Thomas Sharpe

\footnotetext{
${ }^{275}$ Steven William May, Henry Stanford's Anthology: An Edition of Cambridge University Library Manuscript Dd. 5. 75, PhD thesis, University of Chicago, 1968, pp.184-5.

${ }^{276}$ Ibid., pp.xvii-xviii.

277 TNA SP $12 / 252$ ff.176r-177r.

${ }^{278}$ Calendar of Assize Records, Sussex, pp.301-2.

${ }^{279}$ Bacon, Works, Vol. 2, p.342.

${ }^{280}$ Calendar of Assize Records, Sussex, pp.301-2.
} 
that "the Queene would be taken away." When they asked how he knew, he answered "by a prophesie made three hundred yeares agoe." The prophecy predicted that "the Queene should live but three yeares [more] and that this was the Whyte Sommer wherein should be rumors of wars and noe wars come to passe."281

In Scotland, too, the date of Elizabeth's death was a matter of prophetic speculation, especially given that such foreknowledge would be useful for those who supported James VI's claim as her successor. One of James's courtiers, William Fowler, calculated that Elizabeth would die in 1603 by adding together the Roman numerals from the sentence "pace inter Anglos et Hispanos infracta, regina morietvr; et Scoto regi regna sva, ex probo popvli consensv absqve tvrbă, relinqvet [breach of peace between the English and the Spaniards, the queen will die, and the king of the kingdom of the Scots have his own, without the consent of the people, or approval of the people, that he shall leave.]"282

\section{Prophecy and the Union of the Crowns}

Though Elizabeth still refused to name a successor, by the 1590s James VI of Scotland was the de facto heir to her throne. Prophecies circulating in both Scotland and England strengthened his claim and legitimised the union of the crowns. The English agent George Nicolson reported to Sir Robert Cecil from Edinburgh that in the summer of 1599 "a number of books conteynineg annagrams and prophesies applied to" James's succession had been printed "to be dispersed to persuaide the people of [this] and to be ready against the woefull day" of Her Majesty's death. ${ }^{283}$

In 1603 the King's own printer, Robert Waldegrave, contributed to this literature with The Whole Prophesie of Scotland, England, \& Somepart of France. Waldegrave probably published the book in Edinburgh prior to his move to London with James, but the surviving copies appear to be London piracies, demonstrating that there was interest in these prophecies on both sides of the border. ${ }^{284}$ The collection contained prophecies attributed to Merlin, Bede, John of Bridlington, Gildas, and Thomas the Rhymer, among others. Two of these mentioned the son of a French wife who should "rule all Bretaine to

\footnotetext{
${ }^{281}$ Calendar of Assize Records, Surrey, p.487.

${ }^{282}$ TNA SP 12/276 f.190r. The numerals MCCCCLLLXVVVVVVVIIIIIIII add to 1603.

${ }^{283}$ TNA SP 52/65 f.88r.

${ }^{284}$ William A. Jackson, 'Robert Waldegrave and the Books he Printed or Published in 1603', The Library, $5^{\text {th }}$ series, Vol.13, no.4, 1958, p.231.
} 
the sey," a prophecy which, as we have seen, was applied to Mary Stuart and her son by Alexander Scott in $1562 .{ }^{285}$ The prophecy which had appeared in 1570 that:

How euer it happen for to fall,

The Lyon shal be Lord of all

was also reproduced in The Whole Prophesie, with the lion of Scotland now representing James VI. ${ }^{286}$ The final prophecy in the collection, "pronounced be a Noble Queene and Matron called Sibylla Regina Austri... maketh mention of two Noble Princes and Emperours the which is called Leones" who "shall subdue and ouercome all earthlie Princes," and the editor asserted that the second of these was "the sixte King of the name of Steward of Scotland the which is our moste Noble King.",287

In England the sedition laws prevented open discussion of Elizabeth's successor, but nevertheless speculation on the matter did occur. One example is Sir John Harington's Tract on the Succession to the Crown, completed on 18 December, $1602 .{ }^{288}$ The manuscript belonged to Archbishop Tobias Matthew, who was apparently given it by Harington to convince him of the suitability of James as Elizabeth's successor. ${ }^{289}$ Among his justifications Harington included two Welsh prophecies, which he directed "specially to Catholiques," they being "generallie charged to be more superstitious and credulous, and to attribute more to old prophecies and traditions of men then either Protestantes or Puritans." 290 The first, which he claimed to be "elder then my great grandfather," he translated as follows:

A King of Brittish blood in Cradell crownd,
With Lyon markt, shall joine all Brutus ground,
Restore the Crosse, and make this ile renoen'd.

Archbishop Matthew made a marginal note here that "The K. of Scottes is said to have a mole like a Lyon." Harington's own interpretation of the prophecy was:

\footnotetext{
${ }^{285}$ Laing, Collection of ancient Scottish prophecies, pp.16, 25.

${ }^{286}$ Ibid., p. 16.

${ }^{287}$ Ibid., p.48.

${ }^{288}$ Sir John Harington, A Tract on the Succession to the Crown, Clements R. Markham (ed.) (London: J. B. Nichols and Sons, 1880) p.viii.

${ }^{289}$ Jason Scott-Warren, Sir John Harington and the Book as Gift (Oxford: Oxford University Press, 2001) pp. $158-60$.

${ }^{290}$ Harington, p. 120.
} 
That sith a Cradle saw him first a King,

King's offspring shall him store of Cradels bring;

And, since the badge of Judah is the Lyon,

Where Maries sonne the King of Kings did spring,

This King shall onely serve the Lord of Syon.

And shall his crosse and service true advance

In England, Scotland, Ireland, Wales, and Fraunce. ${ }^{291}$

The second prophecy, composed under Henry VIII "and made as it were to the King himself, and yet pointing in my understanding to the Scottish Kings and his issew," declared that:

After mournfull tymes there must ensew

A King of many noble bloods and kindred

Nyne shall succeed in name \& not be hindered. ${ }^{292}$

Harington was not alone in his interpretation of such prophecies; in his own judgment on the succession question the parliamentarian Peter Wentworth had commented that Welshmen were drawn to support James based on the "credite of their old prophecie books. ${ }^{293}$

Despite his statement that Papists were considered more prone to heeding prophecies, Harington also employed prophecy when addressing Protestants. He wrote that while "the wiser sort do for the most part utterly scorn" prophecies, "yet I fynde they give a presage, and leave an impression in their myndes that seeme most to scorn them." He quoted the HEMPE prophecy, his version reading:

After Hempe is sowen and growen

Kings of England shall be none.

Harington recorded three different ways that this prophecy had been interpreted: first, "that the realme should be againe divided into an heptarchie" of seven kingdoms, referring to the period of English history from the end of Roman occupation until the $9^{\text {th }}$ century when the House of Wessex became dominant; second, "that like to the Low

\footnotetext{
${ }^{291}$ Ibid., p.121.

292 Ibid., p.122.

${ }^{293}$ Peter Wentworth, A treatise containing M. Wentworths ivdgement concerning the person of the trve and lawfull successor to these Realmes of England and Ireland (Edinburgh, 1598) pp.63-4.
} 
Countrie wee should be governed by States;" and third, that England would be conquered by "the King of Spaine, whereby wee should be governed by a Viceroy." "294 He then offered the succession of King James as "a meanes how to performe without spoile or bloodshed this prodigious prophecy." 295

There is no clear evidence to indicate whether Harington distributed his tract beyond Archbishop Matthew prior to James's accession. While obviously intended for a wider audience, being addressed to "all trew Englishmen," he acknowledged the 1581 statute forbidding discussion of the succession and wrote that "till it be lawfull to publishe it... I will I say but write it and think it." ${ }^{, 296}$ It certainly received wider circulation after Elizabeth's death, however, since Thomas Phelippes took detailed notes from a copy, and Sir William Morris mentioned the first Welsh prophecy "translated by Sir John Harington" in parliament in March $1604 .^{297}$

In the years following the defeat of the Spanish Armada economic conditions in England declined while religious repression intensified, and the proliferation of prophecies of Elizabeth's death during this period reflect her decreasing popularity as a result. In addition, her advanced age meant that preparations for the succession became all the more important, and when she died on 24 March, 1603, prophecy proved valuable in validating the transition to a new dynasty under James VI and I. An Edinburgh man, Robert Birrel, wrote on 5 April that "all the hail commons of Scotland yat had red or understanding, wer daylie speiking and exponeing of Thomas Rymer hes prophesie, and of uyr: prophsies qlk wer prophesied in auld tymes," namely the HEMPE prophecy, that of the French wife's son, and another in broken Latin that "Post Iaco, ia et ia, coyne, quinto et filius solo regnabat utroque [after the fifth James, the son ruled alone over both.]"298 The image of James as the fulfilment of ancient prophecy, "that King... of whom the Bards and mystick Sibylis sung," served as effective propaganda for the consolidation of his regime. ${ }^{299}$

\footnotetext{
${ }^{294}$ Harington, p. 17.

${ }^{295}$ Ibid., p. 18.

${ }^{296}$ Ibid., pp.3, 39.

${ }^{297}$ CP 139/108; David Harris Wilson (ed.), The Parliamentary Diary of Robert Bowyer, 1606-1607 (New York: Octagon, 1971) p.189; Scott-Warren, pp.167-72.

298 'The Diarey of Robet Birrel', in J. G. Dalyell (ed.), Fragments of Scotish History (Edinburgh, 1798) p.59. The Latin prophecy is also found in The Whole Prophesie of Scotland (Laing, p.42).

${ }^{299}$ Thomas Ruddiman (ed.), The works of William Drummond, of Hawthornden (Edinburgh, 1711) p.37. For more on this point see David Allan, “Arthur Redivivus': Politics and Patriotism in Reformation
} 


\section{CONCLUSION}

The fact that accusations of prophetic activity were used to defame individuals and condemn political agendas complicates any attempt to discern the actual extent of prophetic activity and belief in Elizabethan England. Many of the cases discussed in this thesis were undoubtedly invented, and the significance of plots against the Queen and their prophetic (and therefore demonic) component were often exaggerated in the service of a religiously conservative agenda, justifying the institutionalised persecution of Catholics from the beginning of Elizabeth's reign and Puritans in the early 1590s. Nevertheless, there is adequate evidence to confirm that prophecy as a political discourse was employed and understood across all levels of English society.

The visions of the future depicted in prophecies which circulated during Elizabeth's reign reveal some of the concerns of her subjects. One of the primary issues was religion. The Elizabethan Religious Settlement was met with resistance by recusants in England and condemnation from the international Catholic powers, and these tensions only increased over the course of Elizabeth's reign. Many envisioned that a change of leadership would see a return to the old religion. This was especially true while Mary Queen of Scots lived, but prophecies of the restoration of Catholicism persisted even in Elizabeth's last years. Puritans who favoured further reform to the Church of England also appealed to prophecy, specifically in the form of divine revelation.

Elizabeth's refusal to nominate a successor or marry and produce an heir contributed to the popularity of political prophecy during her reign as it greatly increased uncertainty about what would happen after she died. This was an especially significant factor for members of the Court, whose fortunes depended so much on royal favour, but also greatly concerned the general population. Prophecies relating to the succession reveal discontent with Elizabeth's possession of the throne as an unmarried woman. With the exception of Mary Queen of Scots, all of Elizabeth's prophesied successors were male, and when Mary was prophesied as the next ruler it was invariably alongside a husband.

Among the lower classes economic concerns were also prominent, evident by the role of prophecies in enclosure protests, such as those in 1569 and 1593, and expressions of discontent relating to agricultural crises. For those least privileged by the political and 
economic structures of Elizabethan England, prophecies proved popular that promised a new system of governance altogether, such as the four peers, which it was believed would bring about a golden age.

Prophecy justified political actions by suggesting that they were in accordance with God's plan. The government took very seriously the potential for this to be used against them, as reflected in their efforts to control which prophecies were spread, and to promote the idea that any that challenged established authority revealed the devil's influence. Prophecy was not only "an instrument of political opposition," ${ }^{300}$ however, and those in positions of power sought out knowledge of the future themselves in order to guide their decision-making.

Prophecy also played a role in the international power struggles of late sixteenthcentury Europe, with the relationship between England and other powers frequently providing the subject of prophecy. Due to the shared history, close cultural exchange, and dynastic links between England and Scotland, the prophesied union of these two realms was a recurring subject over the course of Elizabeth's reign. In the 1590s, when England's hold in Ireland was challenged by rebellion, their relationship too became a popular matter for prophetic speculation. Of those kingdoms outside of the British Isles Spain featured most prominently in prophecies, particularly once open warfare broke out.

Prophecies were commonly exchanged between England and the Continent as well as within Britain itself. Diplomats to and from England frequently commented on prophecies in their correspondence, and several prophecies originating in Continental Europe came to play a significant role in politics in England, including those of Nostradamus, Regiomontanus, and Paul Grebner. An examination of sources available outside of Britain could provide a better understanding of the European-wide circulation of prophecies and the role that they played in international politics.

${ }^{300}$ Dobin, p.134. 


\section{BIBLIOGRAPHY}

\section{Manuscript Collections}

British Library

Additional Manuscripts

Cotton Caligula

Cotton Galba

Harley

Lansdowne

Hatfield House

Cecil Papers

Longleat House

Dudley Papers

The National Archives (UK)

Privy Council Registers

Records of the Duchy of Lancaster

State Papers

\section{Primary printed}

A declaration of great troubles pretended against the realme by a number of seminarie priests and Jesuits (London, 1591).

à Geveren, Sheltco, Of the ende of this world, and seconde commyng of Christ, a comfortable and necessary Discourse, for these miserable and daungerous dayes, trans. Thomas Rogers (London, 1577).

Arthington, Henry, The seduction of Arthington by Hacket especiallie, with some tokens of his vnfained repentance and Submission (London, 1592).

Bancroft, Richard, A Sermon Preached at Paules Cosse the 9 of Februarie, being the first Sunday in the Parlieament, Anno 1588 (London, 1588).

—, Davngerovs positions and proceedings, published and practised within this Iland of Brytaine (London, 1593).

Cipriano, John and Vandermers, Tarquatus, A most strange and vvonderfull prophesie vpon this troublesome world, trans. Anthony Hollaway (London, 1595).

Cosin, Richard, Conspiracie for Pretended Reformation (London, 1592). 
Covel, William, Polimanteia, or, the means lawfull and unlawfull, to ivdge of the fall of a common-wealth, against the friuolous and foolish coniectures of this age (London, 1595). Coxe, Francis, A short treatise declaring the detestable wickednesse, of magicall sciences, as Necromancie. Coniurations of spirites, Curiouse Astrologie and suche lyke (London, 1561).

Fulke, William, Antiprognostication that is to saye, an inuectiue against the vayne and vnprofitable predictions of the astrologians as Nostrodame, \&c. (London, 1560).

- The text of the New Testament of Iesus Christ (London 1633).

Harvey, John, A Discovrsive Probleme concerning Prophesies, How far they are to be valued, or credited, according to the surest rules, and directions in Divinitie, Philosophie, Astrologie, and other learning (London, 1588).

- , An astrologicall addition, or supplement to be annexed to the late discourse vpon the great coniunction of Saturne, and Iupiter (London, 1583).

Harvey, Richard, An astrological discourse vpon the great and notable coniunction of the tvvo superior planets, Saturne \& Iupiter, which shall happen the 28 day of April, 1583 (London, 1583).

Heath, Thomas, A manifest and apparent confutation of an astrological discourse, lately published to the discomfort (without cause) of the weake and simple sort (London, 1583). Hill, Thomas, The moste pleasaunte Arte of the Interpretacion of Dreames (London, 1576).

Holinshed, Raphael, The firste volume of the chronicles of England, Scotlande, and Irelande (London, 1577).

Howard, Henry, A defensatiue against the poison of supposed prophecies (London, 1583).

—. A defensatiue against the poison of supposed prophecies... Now newly reuised (London, 1620).

Kyffin, Maurice, The blessedness of Brytaine... Newly set foorth (London, 1588).

Leowitz, Cyprian, De coniunctionibus magnis insignioribus superiorum planetarum, solis defectionibus, \& cometis, in quarta monarchia, cum eorundem effectuum historica exposition (London, 1573).

Maxwell, James, Admirable and Notable Prophecies (London, 1615).

Norton, Thomas, A Warning against the dangerous practices of papistes (London, 1569). Nostradamus, Michel, The Prognostication of maister Michael Nostredamus, Doctour in Phisick. In Prouince for the yeare of our Lorde, 1559 (Antwerp, 1558). 
Parsons, Robert, A briefe apologie, or defence of the Catholike ecclesiastical hierarchie (Antwerp, 1601).

Perkins, William, Foure great lyers, striuing who shall win the siluer whetstone. Also, a resolvtion to the country-man, prouing it vtterly vnlawfull to buye or vse our yearly Prognostications (London, 1585).

Ramsay, Laurence, The practise of the diuell (London, [1577]).

Riche, Barnabe, The true report of a late practise enterprised by a Papist (London, 1582).

Rogers, Thomas, The general session conteining an apologie of the most comfortable doctrine concerning the ende of this world, and seconde coming of Christ (London, 1581).

Stubbes, Phillip, The second part of the anatomie of abuses conteining the display of corruptions (London, 1583).

Tanner, Robert, A prognosticall iudgement of the great coniunction of the two superior planets, Saturne and Iupiter, which shall happen the 8. day of Aprill. 1583 (London, 1583).

Topsell, Edward, Times Lamentation (London, 1599).

Vaughan, Lewes, A Newe Almanacke and Prognostication, Collected for the yeare of our Lord God .M.D.L.IX. (London, 1559).

Wentworth, Peter, A treatise containing M. Wentworths ivdgement concerning the person of the trve and lawfull successor to these Realmes of England and Ireland (Edinburgh, 1598).

Withers, George, Vaticiniu votivum or, Palaemon's prophetick prayer... To which is annexed a paraphrase on Paulus Grebnerus's prophecie (London, 1649).

\section{Primary Source Collections and Calendars}

Calendar of Letters and State Papers relating to England and Spain, 19 vols. (London, 1862-1947).

Calendar of State Papers relating to Ireland, of the reigns of Henry VIII, Edward VI, Mary, and Elizabeth, 11 vols. (London, 1860-1912).

Calendar of State Papers relating to Scotland and Mary Queen of Scots, 13 vols.

(Edinburgh, 1898-1969).

Calendar of State Papers Foreign, Elizabeth, 1558-1589, 23 vols. (London, 1863-1950).

The Statutes of the Realm, Vol. 4 (London, 1819). 
Arber, Edward (ed.), A Transcript of the Registers of the Company of Stationers of London, 2 vols. (London, 1875).

Bacon, Francis, The Works of Francis Bacon, Vol. 2 (London, 1819).

Bannatyne, Richard, Memorials of Transactions in Scotland, Robert Pitcairn (ed.)

(Edinburgh: Bannatyne Club, 1836).

Bateson, Mary (ed.), Records of the Borough of Leicester, Vol. 3 (Cambridge: Cambridge University Press, 1905).

Bruce, John and Perowne, Thomas Thomason (eds.), Correspondence of Matthew Parker, D.D., Archbishop of Canterbury (Cambridge: Cambridge University Press, 1853).

Cockburn, J. S. (ed.), Calendar of Assize Records, Essex Indictments Elizabeth I (London: Her Majesty's Stationery Office, 1978).

- Calendar of Assize Records, Surrey Indictments: Elizabeth I (London: Her Majesty's Stationary Office, 1980).

—, Calendar of Assize Records, Sussex Indictments: Elizabeth I (London: Her Majesty's Stationary Office, 1975).

Cranstoun, James (ed.), The Poems of Alexander Scott (Edinburgh: William Blackwood and Sons, 1896).

Dalyell, J. G. (ed.), Fragments of Scottish History (Edinburgh, 1798).

Dee, John, Autobiographical Tracts, James Crossley (ed.) (Whitefish: Kessinger Publishing, 2003).

d'Ewes, Sir Simonds, The Journals of all the Parliaments during the reign of Queen Elizabeth, Paul Bowes (ed.) (London, 1682).

Green, Mary Anne Everett (ed.), Calendar of State Papers, Domestic Series, of the Reign of Elizabeth, 1591-1594 (London: Longman \& Co., 1867).

— Calendar of State Papers, Domestic Series, of the Reign of Elizabeth, 1595-1597 (London: Longman \& Co., 1867).

- Calendar of State Papers, Domestic Series, of the Reign of Elizabeth, 1598-1601 (London: Longman \& Co., 1867).

- Calendar of State Papers, Domestic Series, of the Reign of Elizabeth, 1601-1603 with Addenda 1547-1565 (London: Longman \& Co., 1870).

- Calendar of State Papers, Domestic Series, of the Reign of Elizabeth, Addenda 1566-1579 (London: Longman \& Co., 1871).

- Calendar of State Papers, Domestic Series, of the Reigns of Elizabeth and James I, Addenda, 1580-1625 (London: Longman \& Co., 1872). 
Harington, Sir John (ed.), Nuga Antiqua: being a miscellaneous collection of original papers in prose and verse (London, 1804).

Harington, Sir John, A Tract on the Succession to the Crown, Clements R. Markham (ed.) (London: J. B. Nichols and Sons, 1880).

Hartley, T. E. (ed.), Proceedings in the Parliaments of Elizabeth I, Vol. 1 (Leicester: Leicester University Press, 1981).

Haynes, Samuel (ed.), A Collection of State Papers, relating to affairs in the reigns of King Henry VIII, King Edward VI, Queen Mary, and Queen Elizabeth, transcribed from original letters and other authentick memorials, left by William Cecil Lord Burghley, Vol. 1 (London: William Bowyer, 1740).

Howell, T. B. (ed.), A Complete Collection of State Trials and Proceedings for High Treason and other Crimes and Misdemeanours (London, 1816).

James, Montague Rhodes (ed.), The Western Manuscripts in the Library of Trinity College, Cambridge, Vol. 2 (Cambridge: Cambridge University Press, 1901).

Lemon, Robert (ed.), Calendar of State Papers, Domestic Series, of the Reign of Elizabeth, 1581-1590 (London: Longman \& Co., 1865). , Calendar of State Papers, Domestic Series, of the Reigns of Edward VI, Mary, Elizabeth, 1547-1580 (London: Longman \& Co., 1856).

Laing, David (ed.), Collection of ancient Scottish prophecies, in alliterative verse (Edinburgh: Ballayntyne \& Co., 1833).

Lodge, Edmund (ed.), Illustrations of British History, 3 vols. (London, 1838).

Melville, James, Memoirs of his own life (Edinburgh: Bannatyne Club, 1827).

Murdin, William (ed.), A Collection of State Papers, relating to affairs in the reigns of King Henry VIII, King Edward VI, Queen Mary, and Queen Elizabeth, transcribed from original letters and other authentick memorials, left by William Cecil Lord Burghley, Vol. 2 (London: William Bowyer, 1759).

Peck, Francis (ed.), Desiderata Curiosa (London, 1779).

Perkins, Willliam, The vvorkes of that famous and vvorthy minister of Christ in the Vniuersitie of Cambridge, Mr. William Perkins (London, 1616-1618).

Petti, Anthony G. (ed.), The Letters and Despatches of Richard Verstegan (London: Catholic Record Society, 1959).

Rigg, J. M. (ed.), Calendar of State Papers relating to English affairs Preserved Principally at Rome in the Vatican Archives and Library (London: His Majesty's Stationery Office, 1916-1926). 
Robbins, R. H. (ed.), Historical Poems of XIVth and XVth Centuries (New York:

Columbia University Press, 1959).

Ruddiman, Thomas (ed.), The works of William Drummond, of Hawthornden (Edinburgh, 1711).

Rye, Walter (ed.), Depositions taken before the Mayor and Alderman of Norwich, 1549-

67 (Norwich: A. H. Goose, 1905).

Smith, Henry, The Sermons of Mr. Henry Smith, Thomas Fuller (ed.), Vol. 2 (London:

William Tegg, 1866).

Wilson, David Harris (ed.), The Parliamentary Diary of Robert Bowyer, 1606-1607 (New York: Octagon, 1971).

Wright, Thomas (ed.), Queen Elizabeth and Her Times, 2 vols. (London: Henry Colburn, 1838).

\section{Books}

Alford, Stephen, The Early Elizabethan Polity: William Cecil and the British Succession Crises, 1558-1569 (Cambridge: Cambridge University Press, 1998).

Bauckham, Richard, Tudor Apocalypse: Sixteenth Century Apocalypticism, Millennarianism, and the English Revolution (Appleford: Sutton Courtenay Press, 1978).

Camden, William, Annals, or, the History of the Most Renowned and Victorious

Princesse Elizabeth, Late Queen of England, trans. R. N. Gent, 3rd ed. (London, 1635).

Capp, Bernard, Astrology and the Popular Press: English Almanacs, 1500-1800 (Boston: Faber, 1979).

Clegg, Cyndia Susan, Press Censorship in Elizabethan England (Cambridge: Cambridge University Press, 2004).

Coote, Lesley A., Prophecy and Public Affairs in Later Medieval England (Woodbridge: Boydell \& Brewer, 2000).

Cressy, David, Dangerous Talk: Scandalous, Seditious, and Treasonable Speech in Premodern England (Oxford: Oxford University Press, 2010).

Dobin, Howard, Merlin's Disciples: Prophecy, Poetry, and Power in Renaissance England (Stanford: Stanford University Press, 1990).

Elton, G. R., The Parliament of England, 1559-1581 (Cambridge: Cambridge University Press, 1989).

- Policy and Police: The Enforcement of the Reformation in the Age of Thomas Cromwell (Cambridge: Cambridge University Press, 1972). 
Firth, Katherine R., The Apocalyptic Tradition in Reformation Britain, 1530-1645

(Oxford: Oxford University Press, 1979).

Graves, Michael A. R., Thomas Norton: The Parliament Man (Oxford: Blackwell Publishers, 1994).

Hessayon, Ariel, 'Gold Tried in the Fire': The Prophet TheaurauJohn Tany and the English Revolution (Aldershot: Ashgate Publishing, 2007).

Jansen, Sharon L., Political Protest and Prophecy under Henry VIII (Woodbridge: Boydell Press, 1991).

Jones, Norman, The Birth of the Elizabethan Age: England in the 1560s (Oxford: Blackwell Publishers, 1996).

Kesselring, K. J., The Northern Rebellion of 1569: Faith, Politics, and Protest in Elizabethan England (Basingstoke: Palgrave Macmillan, 2007).

Leivn, Carole, The Heart and Stomach of a King: Elizabeth I and the Politics of Sex and Power (Philadelphia: University of Pennsylvania Press, 1994).

Maclure, Millar, The Paul's Cross Sermons, 1534-1642 (Toronto: University of Toronto Press, 1958).

Mattingly, Garret, The Armada (New York: Houghton Mifflin Company, 2005).

Nelson, Alan H., Monstrous Adversary: The Life of Edward de Vere, $17^{\text {th }}$ Earl of Oxford (Liverpool: Liverpool University Press, 2003).

Niccoli, Ottavia, Prophecy and People in Renaissance Italy, trans. Lydia G. Cochrane (Princeton: Princeton University Press, 1990).

Parker, Geoffrey, The Grand Strategy of Philip II (New Haven: Yale University Press, 1998).

Parry, Glyn, The Arch-Conjuror of England: John Dee (New Haven: Yale University Press, 2011).

Peck, Linda Levy, Northampton: Patronage and Policy at the Court of James I (London: George Allen \& Unwin, 1982).

Reynolds, Matthew, Godly Reformers and their Opponents in Early Modern England: Religion in Norwich, c.1560-1643 (Woodbridge: Boydell Press, 2005).

Richards, Judith M., Elizabeth I (London: Routledge, 2012).

Scott-Warren, Jason, Sir John Harington and the Book As Gift (Oxford: Oxford University Press, 2001).

Stern, Virginia F., Gabriel Harvey: His Life, Marginalia and Library (Oxford: Oxford University Press, 1979). 
Strohm, Paul, England's Empty Throne: Usurpation and the Language of Legitimation, 1399-1422 (New Haven: Yale University Press, 1998).

Strype, John, Annals of the Reformation and the Establishment of Religion, (Oxford:

Clarendon Press, 1824).

Taith, Bertrand and Tim Thornton (eds.), Prophecy: The Power of Inspired Language in History 1300-2000 (Stroud: Sutton Publishing, 1997).

Tawney, R. H., The Agrarian Problem in the Sixteenth Century (New York: Longmans, Green \& Co., 1912).

Taylor, Rupert, The Political Prophecy in England (New York: Columbia University Press, 1911).

Thomas, Keith, Religion and the Decline of Magic (London: Penguin, 1971).

Thompson, James, The History of Leicester: From the Time of the Romans to the End of the Seventeenth Century (Leicester: J. S. Crossley, 1849).

Thornton, Tim, Prophecy, Politics and the People in Early Modern England (Woodbridge: Boydell Press, 2006).

Traister, Barbara Howard, The Notorious Astrological Physician of London: Works and Days of Simon Forman (Chicago: University of Chicago Press, 2001).

Venn, John (ed.), Alumni Cantabridienses, pt 1, vol. 2 (Cambridge: Cambridge

University Press, 1922).

Walsham, Alexandra, Providence in Early Modern England (Oxford: Oxford University Press, 1999).

\section{Articles}

Allan, David, “'Arthur Redivivus': Politics and Patriotism in Reformation Scotland', in

James P. Carley and Felicity Riddy (eds.) Arthurian Literature XV (Cambridge: D. S. Brewer, 1997) pp.185-204.

Aston, Margaret, 'The Fiery Trigon Conjunction: An Elizabethan Astrological Prediction', Isis, Vol. 16, no. 2, Summer 1970, pp.158-187.

Dodds, Madeleine Hope, 'Political Prophecies in the Reign of Henry VIII', Modern Language Review, Vol. 11, no. 3, July 1916, pp.276-284.

Forster, Jennifer, 'Anticipating the Apocalypse: An Elizabethan Prophecy', The Historian, Vol. 63, no. 3, Spring 2001, pp.600-617. 
Fox, Adam, 'Rumour, News and Popular Political Opinion in Elizabethan and Early Stuart England', The Historical Journal, Vol. 40, no. 3, September 1997, pp.597-620. Fox, Alistair, 'Prophecies and Politics in the Reign of Henry VIII', in Alistair Fox and John Guy, Reassessing the Henrician Age: Humanism, Politics and Reform, 1500-1550 (Oxford: Basil Blackwell, 1986) pp.77-94.

Jackson, William A., 'Robert Waldegrave and the Books he Printed or Published in 1603', The Library, $5^{\text {th }}$ series, Vol. 13, no. 4, 1958, pp.224-33.

Johnson, Francis R., 'Thomas Hill: An Elizabethan Huxley', The Huntington Library Quarterly, Vol. 7, no .4, August 1944, pp.329-51.

Jones, Norman 'Defining Superstitions: Treasonous Catholics and the Act against Witchcraft of 1563', in Charles Carlton, Robert L. Woods, Mary L. Robertson, and Joseph S. Block (eds.), State, Sovereigns \& Society in Early Modern England (New York: St. Martin's Press, 1998), pp.187-203.

Kagan, Richard L., 'Politics, Prophecy, and the Inquisition in Late Sixteenth-Century Spain', in Mary Elizabeth Perry and Anne J. Cruz (eds.), Cultural Encounters: The Impact of the Inquisition in Spain and the New World (Berkeley: University of California Press, 1991) pp.105-124.

Kapelle, Rachel, 'Predicting Elizabeth: Prophecy on Progress', Medieval and Renaissance Drama in England, Vol. 24 (2011) pp.83-105.

Kesselring, K. J., 'Deference and Dissent in Tudor England: Reflections on SixteenthCentury Protest', History Compass, Vol. 163, no. 3, 2005, pp.1-16.

Lynch, Michael, 'Queen Mary's Triumph: The Baptismal Celebrations at Stirling in December 1566', Scottish Historical Review, Vol. 69, no. 187, April 1990, pp.1-21. Parry, Glyn, 'The Monarchical Republic and Magic: William Cecil and the Exclusion of Mary Queen of Scots', Reformation, Vol. 17, 2012, pp.29-47.

—, 'Mythologies of Empire and the Earliest English Diasporas', in T. Bueltmann, D. T. Gleeson and D. M. MacRaild (eds.), Locating the English Diaspora 1500-2010 (Liverpool: Liverpool University Press, 2012) pp.15-33.

Smallwood, T. M., 'The Prophecy of the Six Kings', Speculum, Vol. 60, no. 3, July 1985, pp.571-592.

Van Patten, Jonathan K., 'Magic, Prophecy, and the Law of Treason in Reformation England', The American Journal of Legal History, Vol. 27, no. 1, January 1983, pp.1-32. 
Walsham, Alexandra, “Frantick Hacket': Prophecy, Sorcery, Insanity, and the Elizabethan Puritan Movement', The Historical Journal, Vol. 41, no. 1, March 1998, pp.27-99.

Winship, Michael P., 'Puritans, Politics, and Lunacy: The Copinger-Hacket Conspiracy as the Apotheosis of Elizabethan Presbyterianism', The Sixteenth Century Journal, Vol. 38, no. 2, Summer 2007, pp.345-69.

\section{Online}

British History Online; http://www.british-history.ac.uk

Early English Books Online; http://eebo.chadwyck.com

Google Books; http://books.google.com

Internet Archive; http://archive.org

Medieval and Early Modern Sources Online; http://sources.tannerritchie.com

State Papers Online; http://www.gale.cengage.co.uk/statepapers

The National Archives; http://www.nationalarchives.gov.uk

Adams, Simon, 'Cavendish, Richard (c.1530-1601)', Oxford Dictionary of National

Biography; http://www.oxforddnb.com/view/article/4941; accessed 6 August 2012.

Croft, Pauline, 'Howard, Henry, earl of Northampton (1540-1614)', Oxford Dictionary of National Biography; http://www.oxforddnb.com/view/article/13906, accessed 12 Feb 2013.

Elzinga, J. G., 'Howard, Philip [St Philip Howard], thirteenth earl of Arundel (15571595)', Oxford Dictionary of National Biography;

http://www.oxforddnb.com/view/article/13929; accessed 4 March 2013.

Goring, J. J., 'TUSSER (TYSSARD), Clement (by 1520-61 or later), of Rivenhall, Essex'; The History of Parliament: the House of Commons 1509-1558;

http://www.historyofparliamentonline.org/volume/1509-1558/member/tusser-(tyssard)clement-1520-61-or-later; accessed 12 October 2012.

Graves, Michael A. R., 'Howard, Thomas, fourth duke of Norfolk (1538-1572)', Oxford Dictionary of National Biography; http://www.oxforddnb.com/view/article/13941; accessed 3 September 2012.

Griffiths, R. A., 'Stradling, Sir Thomas (c. 1498-1571)', Oxford Dictionary of National Biography; http://www.oxforddnb.com/view/article/26629; accessed 20 August 2012. 
Hammer, Paul E. J., 'Devereux, Robert, second earl of Essex (1565-1601)', Oxford Dictionary of National Biography; http://www.oxforddnb.com/view/article/7565; accessed 5 March 2013.

MacCaffrey, Wallace T., 'Knollys, Sir Francis (1511/12-1596)', Oxford Dictionary of National Biography; http://www.oxforddnb.com/view/article/15755; accessed 3 Sept 2012.

McCormack, Anthony M., 'Fitzgerald, James fitz Gerald, fifteenth earl of Desmond (c.1570-1601)', Oxford Dictionary of National Biography; http://www.oxforddnb.com/view/article/9563; accessed 29 January 2013. Marshall, Rosalind K., 'Douglas, Lady Margaret, countess of Lennox (1515-1578)', Oxford Dictionary of National Biography; http://www.oxforddnb.com/view/article/7911; accessed 5 June 2012.

Silke, John J., 'O'Donnell, Hugh, lord of Tyrconnell (1572-1602)', Oxford Dictionary of National Biography; http://www.oxforddnb.com/view/article/20554; accessed 6 March 2013.

Turner, A. J., 'Bassantin, James (d. 1568)', Oxford Dictionary of National Biography; http://www.oxforddnb.com/view/article/1632; accessed 13 June 2012. Walsham, Alexandra, 'Hacket, William (d. 1591)', Oxford Dictionary of National Biography; http://www.oxforddnb.com/view/article/11840; accessed 8 March 2013.

\section{Theses}

Devine, Michael J., John Prestall: A Complex Relationship with the Elizabethan Regime, MA thesis, Victoria University of Wellington, 2009.

Ding, Jessica, Political Prophecy in Tudor England, MA thesis, University of Maryland, 2010 .

Forster, Jennifer E., Politics, Prophecy, and Propaganda in Early Modern England, PhD thesis, Kent State University, 2005.

May, Steven William, Henry Stanford's Anthology: An Edition of Cambridge University Library Manuscript Dd. 5. 75, PhD thesis, University of Chicago, 1968. 